Portland State University

PDXScholar

12-10-2021

\title{
Methods of Memorialization: Holocaust Commemoration in the United States Holocaust Memorial Museum
}

Kylee Bolinger

Follow this and additional works at: https://pdxscholar.library.pdx.edu/honorstheses

Part of the European History Commons, Holocaust and Genocide Studies Commons, and the Museum Studies Commons

Let us know how access to this document benefits you.

\section{Recommended Citation}

Bolinger, Kylee, "Methods of Memorialization: Holocaust Commemoration in the United States Holocaust Memorial Museum" (2021). University Honors Theses. Paper 1155.

https://doi.org/10.15760/honors.1191

This Thesis is brought to you for free and open access. It has been accepted for inclusion in University Honors Theses by an authorized administrator of PDXScholar. Please contact us if we can make this document more accessible: pdxscholar@pdx.edu. 


\title{
Methods of Memorialization:
}

Holocaust Commemoration in the United States Holocaust Memorial Museum

\author{
Kylee Bolinger \\ Advisor: Carrie Collenberg-González
}

Honors Thesis

December 10, 2021 
Introduction

As a student of history, I am often struck by the startling similarities between different tragic events, which took place in different times, were perpetuated by different groups of people, and had different victims. No matter which point in history is analyzed, there is a common recurrence in nearly every place, nearly every group, and nearly every time: genocide. It is impossible for contemporary historians to ever understand the full story, for the stories of victims usually die with them, and history is written by the survivors. This paper is my attempt to explore endeavors that have been made to reserve space for these unspoken stories.

Memorials, both formal and informal, both private and public, have long participated in the pursuit to honor the victims of tragedy, disaster, or genocide. Memorial museums serve both to memorialize victims and to foster an environment conducive to reflection and education about these stories. These memorial museums have especially made their mark after one of the most notable and devastating genocide events in history: the Holocaust in twentieth-century Europe. ${ }^{1}$ The American Memorial Council of the Holocaust was formed in 1980, and charged with planning the United States Holocaust Memorial Museum, (USHMM), which opened in $1993 .{ }^{2}$ The USHMM was founded as a national American monument, attempting to honor victims of the Holocaust, and to share their stories. In what follows, I explore many aspects of memorialization within the USHMM. I wanted to discover the kind of meaning the museum was hoping to establish, and determine whether or not this was successful. I conclude that the USHMM sought to establish authenticity through rhetorical means, weaving their artifact choices

\footnotetext{
${ }^{1}$ Hansen-Glucklich, Jennifer. Holocaust Memory Reframed : Museums and the Challenges of Representation. New Brunswick, New Jersey: Rutgers University Press, 2014, 2, 10.

${ }^{2}$ Wieviorka, Annette. The Era of the Witness. Translated by Jared Stark. Ithaca, N.Y: Cornell University Press, 2006, 106-107.
} 
through the lens of a predetermined narrative. ${ }^{3}$ This narrative is eerily similar to the United States' preexisting, singular Holocaust narrative which arose in the 1960s, where specific, oversimplified tropes of victims, perpetrators, and heroes were favored in the United States' medial depictions of the Holocaust. ${ }^{4}$ These memorialization methods make up the American interpretation of Vergangenheitsbewältigung, the concept typically applied to how Germans deal with or face the aftermath of the Second World War.

Many sources have informed my research but this project leans heavily on the work of a few key texts that form the structure and method of my approach. Extensive research has been done in the fields of Trauma, Memory, Holocaust, and Genocide Studies, and many scholars reference the works of experts like Émile Durkheim and Walter Benjamin to inform their theories. Works by experts such as Maurice Halbwachs and Marianne Hirsch, as well as others, provide the background information needed for this project. ${ }^{5}$ My research on the topic of Holocaust memorialization comes from both the extensive study of experts, and from my own experience. I visited the USHMM in Washington, D.C. in fall 2021, in order to see, in person, the memorial techniques which I had read so much about. While there, I took nearly 600 pictures of various artifacts and framing techniques, several of which can be found in Appendix A. ${ }^{6}$ I also brought a journal, in which to record the thoughts and impressions I might have along the way, as well as to document the less tangible, more sensorial framing devices, like sound or smell,

\footnotetext{
${ }^{3}$ Bernard-Donals, Michael F. Figures of Memory: The Rhetoric of Displacement at the United States Holocaust Memorial Museum. Albany: SUNY Press, 2016, 59, 63.

${ }^{4}$ Wieviorka, The Era of the Witness, 100-101. The collective narrative about the Holocaust in the United States favors certain caricatures of victims, heroes, and perpetrators over others, and doesn't have room for other memories of events. It is a vast oversimplification of the Holocaust into a simple, Hollywood-esque trope of victim/perpetrator/hero.

${ }^{5}$ Halbwachs, Maurice. On Collective Memory. Translated by Lewis A. Coser. Chicago, IL: University of Chicago Press, 1992; Hirsch, Marianne. The Generation of Postmemory: Writing and Visual Culture after the Holocaust. New York, NY: Columbia University Press, 2012. Further sources may be found in the Bibliography at the end of this thesis.

${ }^{6}$ See Appendix A.
} 
which might be employed by the museum. Work by scholars Michael Bernard-Donals, Paul Williams, Jennifer Hansen-Glucklich, Marianne Hirsch, and Annette Wieviorka have informed the core of my approach.

In his book, Figures of Memory: The Rhetoric of Displacement at the United States Holocaust Memorial Museum, Michael Bernard-Donals explores how the USHMM uses its design to create authentic memory within its visitors. Much of my knowledge about the decisions of the USHMM's planning committee comes from this text and Bernard-Donal's analysis of documents produced by the museum and comments from visitors, as well as through his own observation of the museum's permanent exhibition. Many documents created by the USHMM's planning committee are cited here and demonstrate what the committee sought to accomplish through the museum's design. ${ }^{7}$ Bernard-Donals argues that the USHMM does not merely place the Holocaust into a logical historical order. Rather, it "creates... an exchange", which "moves" the visitor to do something about the things they've just learned and the feelings they've had. In his eyes, the USHMM is successful in moving and shaping memory in visitors, leading them to apply the uncomfortable feelings they experience at the museum to contemporary topics. ${ }^{8}$

I also rely heavily on the classifications of museum artifacts in Paul Williams' book Memorial Museums: The Global Rush to Commemorate Atrocities, Williams critically analyzes methods used by memorial museums to commemorate past events like the Holocaust. ${ }^{9}$ He also breaks down the use of photographic evidence, and some of the nuances involved with that, and I use these classifications, again, to further break down and analyze specific examples from the USHMM. In Chapter One: Artifacts, I incorporate these classifications and also compare them to

\footnotetext{
${ }^{7}$ Bernard-Donals, Figures of Memory, 59.

${ }^{8}$ Ibid., 184.

${ }^{9}$ Williams, Paul Harvey. Memorial Museums: The Global Rush to Commemorate Atrocities. English ed. Oxford; New York: Berg, 2007, 25-28.
} 
the USHMM's goals regarding artifacts and authenticity upon designing the museum. I also use Williams' guidelines to shape my own observations about specific inclusions of artifacts within the USHMM's permanent exhibit.

In Holocaust Memory Reframed, Jennifer Hansen-Glucklich discusses methods of Holocaust memorialization in three museums; Daniel Libeskind's “Jewish Museum Berlin”, "Yad Vashem" in Jerusalem, and the USHMM. She discusses how each museum chooses to memorialize the past differently, and argues that each museum's Holocaust narrative is delivered within historical and cultural contexts specific to the country in which they are found ${ }^{10}$ She also discusses these narratives within a lens of "the sacred." According to Hansen-Glucklich, Yad Vashem in Jerusalem relies on the role of sacred remembrance in Judaism to tell its story, while Libeskind's Jewish Museum focuses on the "negative sacred" of Jews' noticeable absence in contemporary Germany. In contrast, the USHMM focuses primarily on “American” ideals democracy, freedom, pluralism, and individual rights - as a kind of sacred opposition to twentieth century Germany’s fascism. ${ }^{11}$ In Chapter Two: Title, I use several of Hansen-Glucklich's ideas about various framing methods - architectural choices, interior framing devices, and sensorial devices - to discuss how these techniques are employed by the USHMM, and the kind of effects produced by each method. I also incorporate her understanding of how framing devices are employed in other Holocaust memorial museums around the world, as a counterexample to the methods employed by the USHMM.

Marianne Hirsch also extensively discusses the use of photographic evidence in contemporary memorial museums in The Generation of Postmemory: Writing and Visual Culture

\footnotetext{
${ }^{10}$ Hansen-Glucklich, Holocaust Memory Reframed, 2-6.

${ }^{11}$ Ibid., 77.
} 
After the Holocaust.$^{12}$ She specifically discusses the balance memorial museums must maintain between "action" and "identification" photographs, in order to bring what she calls "embodied remembrance" into symbolic memorial practice. ${ }^{13}$ This embodied remembrance, according to Hirsch, is a key element memorial museums need to include, in order to elevate memorialization into empathy, spurring action. Hirsch also discusses the concept of postmemory - the memory people inherit from their parents instead of one they directly experience themselves which is "memory-like" in its affective force on the human psyche; even those who did not experience the traumatic events themselves may display trauma-like effect. ${ }^{14}$ This postmemory leads to an intergenerational passing-down of memory among generations, and those who experience this postmemory and want to share it publicly convert postmemory into a public form, a kind of cultural remembrance. This cultural remembrance cultivates what many call collective memory, which I discuss in Chapter Three: Collective Memory. ${ }^{15}$

Annette Wieviorka's The Era of the Witness discusses the positives and negatives surrounding the use of eyewitness testimony to recount a past as significant as the Holocaust. ${ }^{16}$ According to her, witness testimony is notoriously unreliable, because it is always shaped by the discourses and ideas prevalent in a society at the time it is given. Testimony alone, according to Wieviorka, is incapable of generating a fully factual historical narrative. Wieviorka goes on to discuss the history of Holocaust memory in the United States, addressing evolving sentiments toward witness testimony in the writing of this history. ${ }^{17}$ She also discusses how this history

\footnotetext{
${ }^{12}$ Hirsch, Marianne. The Generation of Postmemory: Writing and Visual Culture after the Holocaust. New York, NY: Columbia University Press, 2012, 31-38.

${ }^{13}$ See Williams' classification of her approach to photographs using his terms:

Williams, Memorial Museums, 25.

${ }^{14}$ Hirsch, The Generation of Postmemory, 31.

${ }^{15}$ Ibid., $31-38$.

${ }^{16}$ Wieviorka, The Era of the Witness, xii-xiv.

${ }^{17}$ Ibid., 100.
} 
plays into contemporary ideas about memory and memorialization. I discuss these and other ideas regarding memory studies in Chapter Three: Collective Memory. In this chapter, I also address some of the criticisms associated with these terms, and some of the downsides to their use. Finally, I discuss how the USHMM has attempted to shape these memorial concepts for its own use, as well as how it has fallen into some of the traps itself.

Many other sources have informed my work and are listed in the "Bibliography". Though much work has been done in related fields, this project has helped me delve deeper into the methods of memorialization implemented by the USHMM, and to discuss how these methods are tied together into a cohesive narrative about the Holocaust. As I have researched the origins of the USHMM and its planning committee, I have come to learn that the USHMM sought to establish authenticity through mainly rhetorical means, basing their artifact choices on how well they fit into the predetermined Holocaust story, as can be seen in the documents published the planning committee in charge of designing the USHMM. ${ }^{18}$ Though the USHMM seeks, in various ways, to avoid oversimplifying this narrative, they instead end up reinforcing this oversimplification by failing to adequately disrupt or expand visitors' preconceived ideas about the Holocaust story. This predetermined narrative, as it turns out, is eerily similar to the United States' preexisting, singular Holocaust narrative which arose in the 1960s. ${ }^{19}$ This thesis is divided into three chapters. Chapter One discusses artifacts, analyzing the USHMM's goals in acquiring them, and how the museum uses them in its permanent exhibition. It also discusses the categorization of artifacts, using Williams' categories. ${ }^{20}$ Chapter Two goes over the use of framing devices to contribute to the museum's overall narrative. These framing devices include physical framework such as architecture, lighting, use of space, the overall layout of the

${ }^{18}$ Bernard-Donals, Figures of Memory, 59-63.

${ }^{19}$ Wieviorka, The Era of the Witness, 100.

${ }^{20}$ Williams, Memorial Museums, 25. 
exhibition, and other factors. Framing devices may also include sensorial effects such as sound and smell. Chapter Three discusses collective memory, going over definitions of related terms by various scholars, as well as discussing how these ideas apply to the USHMM and its interpretation of the Holocaust story. The conclusion then summarizes these chapters and discusses the USHMM in the context of the United States and its own processes of Vergangenheitsbewältigung. Here, I discuss what having a cohesive story like this about a complex event can imply about the United States as a nation, and how it chooses to represent (or repress) its own relationship to the violent past. Though the USHMM seeks, in various ways, to avoid oversimplifying this narrative, they instead end up reinforcing this oversimplification by failing to adequately disrupt or expand visitors' preconceived ideas about the Holocaust story. 


\section{Chapter One: Artifacts}

Artifacts are integral to museums and how they establish authenticity for the story they aim to represent and therefore play a large role in secondary literature. According to Michael Bernard-Donals, artifacts are, in the case of memorial museums, "objects tied to abhorrent events", that function as evidence confirming an event's occurrence, and serve to "give displays a powerful appeal." ${ }^{21}$ An important factor to remember when contemplating objects within a memorial context, is that the "clandestine nature of much political violence means that perpetrators aim to purposefully destroy evidence of their destruction," making that which $i s$ recovered all the more valuable. Jennifer Hansen-Glucklich suggests that, often, Holocaust artifacts are used to "anthropomorphically symbolize Jewish victims", and suggests that artifacts possess "witnessing vision", or, "a way of seeing that responds to authentic artifacts within displays that are presented as witnesses to atrocities." ${ }^{22}$ She discusses philosopher Giambattista Vico's idea of "manifest testimony" - that objects inherently have greater authority than oral testimonies or text alone. Though far removed - in both time and space - from the represented catastrophic event, viewers who behold authentic artifacts in this context are able to come a little closer to the represented traumatic experience through the objects' "authentic presence."

In this chapter I discuss artifact inclusion and categorization in memorial museums, using the example of specific objects included in the permanent exhibition of the USHMM. In Section I: The USHMM's Authenticity Goals, I discuss the USHMM's goals regarding artifacts and authenticity, upon designing the museum. Section II: Categories of Artifacts goes over

\footnotetext{
${ }^{21}$ Bernard-Donals, Figures of Memory, 25.

${ }^{22}$ Hansen-Glucklich, Holocaust Memory Reframed, 119-120.
} 
classifications of artifacts, based on Williams' model. Section III: Photos and Videos as Evidence is specifically devoted to the use of photographs and video footage in a memorial context. In Section IV: The Nuances of Photographic Evidence, I discuss the difficulties and nuances associated with using photographs and videos as evidence in memorial museums. Finally, in section V: The Implications and Functions of Artifacts at the USHMM, I go over some of the implications of specific inclusions of artifacts within the USHMM's permanent exhibit.

Section I: The USHMM's Authenticity Goals

The committee in charge of designing the USHMM had a twofold goal in building the memorial museum. ${ }^{23}$ First, they sought to memorialize and honor the victims of the Holocaust of the mid-twentieth century, and second, they wanted to educate the public about the violent events which transpired. In order to achieve both goals simultaneously, they agreed that "authenticity" was one of the most important things they could strive for as a memorial museum. ${ }^{24}$ However, the real struggle arose in defining authenticity. The USHMM's planning committee sought to find a way to remain true to the "Holocaust story" in a manner that was respectful to all of its victims, without veering toward gross oversimplification of a complex, even incomprehensible, event. ${ }^{25}$ Thus, the USHMM sought to convey a cohesive message and their specific idea of the Holocaust story. Although they sought to be as true to history as possible, they ended up placing significant emphasis upon traditionally American values and their opposition to twentieth-century Germany's fascism. ${ }^{26}$ These American values shine through the USHMM's

\footnotetext{
${ }^{23}$ Bernard-Donals, Figures of Memory, 49-50.

24 Bernard-Donals, Figures of Memory, 49.

${ }^{25}$ Bernard-Donals, Figures of Memory, 53.

${ }^{26}$ Hansen-Glucklich, Holocaust Memory Reframed, 77.
} 
Holocaust story and include the ideals of democracy, freedom, pluralism, and individual rights. This narrative was intended to be articulated in a manner that would provoke authentic reactions from visitors. An additional reason for the insistance on adhering to authenticity in the USHMM was due to a "recent upsurge in the activities of Holocaust deniers", around the time of its planning and dedication. ${ }^{27}$ However, it must be acknowledged what other types of authentic information about the Holocaust story were lost in the USHMM's appeal to the American public.

Visceral visitor responses were at the root of authenticity for the USHMM's planning committee. ${ }^{28}$ The museum's main criteria for artifact selection was the item's relevance to the museum story. In fact, the provenance of the artifacts themselves didn't matter as much as did their basic historical accuracy: they needed only to have been owned by someone who lived through the Holocaust in some way.${ }^{29}$ As long as the artifacts were a true, authentic part of history, their actual provenance - what happened to these items between the war and their placement at the USHMM - was less important. As such, the USHMM's permanent exhibit consists largely of photographs, artifacts owned or produced by those who lived through the Holocaust - whether that be perpetrators, victims, or another group - and, finally, replicas of objects that the USHMM could not or would not physically acquire.

Part of the draw for the USHMM's use of specific artifacts was their aesthetic appearance. Replicas were made of several items, usually by first making a casting of the original item and then recreating it for the museum's use. But when these replicas were made, it was ensured that they "would have the appearance of the objects as they might have been found if they were forty-five years old, and not... [as] they might have when they were originally made

${ }^{27}$ Elieli, quoted in Hansen-Glucklich, Holocaust Memory Reframed, 127.

${ }^{28}$ Bernard-Donals, Figures of Memory, 53.

${ }^{29}$ Bernard-Donals, Figures of Memory, 59-62. 
or even as they appeared at the end of the war." 30 Thus, these replicas were purposefully created to appear "more dirty," in order to produce the sought-after aesthetic of an aged object, leading ultimately toward the desired, authentic, visitor reaction. This prioritization of authenticity and factity over provenance is controversial, because it allows for the possibility of a kind of black market trade of Holocaust artifacts, where these items were perhaps not willingly relinquished before being sold. ${ }^{31}$ By using replicas to simulate an authentic experience, the museum willingly dismisses an item's provenance, potentially ignores the wishes of artifact donors, recreates and endorses questionable practices surrounding the circulation of artifacts after the end of the war.

The USHMM planning committee sought to bring about the desired visitor response via rhetorical means; that is, through the language and overall message of the museum itself. ${ }^{32}$ The committee believed that this method would help to achieve the best understanding of the past that the museum could provide. It would, in their eyes, make up for the lack of any real inherent 'witnessing' quality of individual artifacts themselves. Then-director of the USHMM's planning council, and future director of the museum, Sara Bloomfield, said that artifacts "assume their value only through the connection to the Holocaust. They are displayed not so much as icons with inherent or independent value, but as supporting elements to a narrative. Objects serve an environmental function, adding ambiance and immediacy to the exhibition experience." 33 The USHMM planning council sought to foster their idea of an emotional response from their visitors with their "Draft Collection Management Policy" in the fall of $1986 .{ }^{34}$

\footnotetext{
${ }^{30}$ Bernard-Donals, Figures of Memory, 59-62.

31 Ibid., 62.

32 Ibid., 63.

${ }^{33}$ Bloomfield, quoted in Bernard-Donals, Figures of Memory, 62.

${ }^{34}$ Bernard-Donals, Figures of Memory, 59.
} 
The "Draft Collection Management Policy" outlined the six most important points regarding artifact acquisition. First and most important was the relevance of each artifact to the museum's purposes; namely, its role in the collection and the museum as a whole. The next point of importance was each artifact's aesthetic quality and/or historical significance, and point three discussed each artifact's potential for exhibition and/or study. The policy's fourth point deliberated the physical condition of the artifact, in relation to transport to the museum, storage, restoration and/or conservation. Fifth, the provenance of each artifact was analyzed, and lastly, conditions imposed by the vendor or donor were to be considered.

An important way in which the USHMM's planning committee intended to engender emotional response from the museum's visitors was to purposefully include items, especially photographs, which were disturbing and difficult to view. ${ }^{35}$ Helen Fagin, a Holocaust survivor and member of the USHMM planning committee, commented that it was "almost necessary" for visitors to be sickened by the truth. ${ }^{36}$ However, the committee did not want to overwhelm visitors with too many graphic images, so a careful balance was planned. Such a balance would ensure that visitors would be adequately distressed, but not so bombarded with violent images that they would become overwhelmed by or numbed to them. With this balance in mind, the committee created a document entitled “A Working Response to the Question of Explicit Imagery Including 'The Pornography of Murder,' Nudity and Violence in a Museum” in February of $1988 .{ }^{37}$ In it, they called for the use of explicit and disturbing images and artifacts, but, at the same time, also for a balance between these and other, less violent images and artifacts which still were effective in storytelling.

\footnotetext{
${ }^{35}$ Ibid., 64.

${ }^{36}$ Ibid.

${ }^{37}$ Bernard-Donals, Figures of Memory, 64-65.
} 
A final concern posed by the planning committee of the USHMM concerned how the museum's permanent exhibition should conclude. Members of the committee were determined to consciously avoid any kind of happy conclusion to their Holocaust story, which would oversimplify the complex narrative and underplay the event's horrors. Instead, they sought to purposefully avoid answering the question of "what now?" for the museum's visitors, by leaving a kind of "void," in lieu of a direct answer. ${ }^{38}$ This discussion led to the design of the museum's current Hall of Remembrance, which is located at the very end of the permanent exhibition. This cavernous room contains the names of all concentration, prison, and death camps of Europe, wrought sharply of metal, and affixed to the walls. There are several Torah quotations engraved in the stone walls above these names. The most prominent display in this spacious room is a large, black, tomb-like monument, atop which burns an eternal flame. The inscription on this monument claims that it contains soil, gathered "from death camps, concentration camps, sites of mass execution, and ghettos in Nazi-occupied Europe, and from cemeteries of American soldiers who fought and died to defeat Nazi Germany." This conscious inclusion of US soldiers in the victim pool is a clear indication of the USHMM's - and, by extention, the US government's view of the American role as "heroes" of the Holocaust story.

Section II: Categories of Artifacts

According to Hansen-Glucklich in Holocaust Memory Reframed: Museums and the Challenges of Representation, memorial museums like the USHMM must meet three main goals. First, they must provide witness, or testimony, of atrocity events. Second, they must facilitate remembrance for those who are capable of remembering the events, and, lastly, they must

${ }^{38}$ Bernard-Donals, Figures of Memory, 65. 
educate visitors on what happened, in order to honor the victims of the past. ${ }^{39}$ According to Paul Williams, the "relationship between the memorial museum and its event is singularly focused." 40 Despite this singular mission, however, the process of choosing artifacts to exhibit as well as the best method for their display is not an easy one. Williams further divides artifacts in these types of museums into categories. First are the types of artifacts he calls "the physical remnants of violence," or the objects essentially "produced" by the perpetrators, or by violence or conflict itself. ${ }^{41}$ These objects may include things like the golden "Jude" (Jew) star ${ }^{42}$ once pinned to a Jew's chest, on display at the USHMM, or the signs stating "Juden sind hier unerwünscht"43 (Jews are not wanted here), which used to hang on the walls outside certain establishments or properties during the Holocaust. Even the USHMM's casting of the "Arbeit Macht Frei" ${ }^{44}$ (Work makes [you] free) sign, wrought in iron, originally attached above the iron gates of Auschwitz, might count in this category. The Zyklon B canisters and pellets on display behind a glass wall at the USHMM would also be part of this group. ${ }^{45}$

Second, Williams denotes a category of artifacts he calls "the discarded", mundane objects which have been prescribed meaning through a force called the "museum effect". ${ }^{46}$ The "museum effect" is a kind of ascription of memorial meaning to otherwise everyday objects, like shoes $^{47}$, cobblestones ${ }^{48}$, damaged Torah scrolls found in synagogues ${ }^{49}$, or even a German railway

\footnotetext{
${ }^{39}$ Hansen-Glucklich, Holocaust Memory Reframed, 10.

${ }^{40}$ Williams, Memorial Museums, 25.

41 Ibid.

${ }^{42}$ See Appendix A, Figure 41.

${ }^{43}$ See Appendix A, Figures 19 and 20.

${ }^{44}$ See Appendix A, Figure 56.

${ }^{45}$ See Appendix A, Figure 57.

${ }^{46}$ Williams, Memorial Museums, 28.

${ }^{47}$ See Appendix A, Figures 62 and 63.

${ }^{48}$ See Appendix A, Figure 44.

${ }^{49}$ See Appendix A, Figure 24.
} 
$\operatorname{car}^{50}$, all of which can be found at the USHMM. These items are often restored and given a plaque or sign to indicate their provenance, thereby elevating them from common items to artifacts of historical magnitude. ${ }^{51}$ The USHMM is home to many castings of original artifacts, which are made with the permission of the city or country in which they are found, to be used specifically at the museum. Such artifacts may have been classified as mundane and unimportant without the connotation of the Holocaust provided by the museum. These castings of "discarded" items on display at the USHMM include cobblestones ${ }^{52}$ from the $\mathrm{Ch} \nmid$ odna Street Ghetto, the Tarnów Jewish Cemetery Gate ${ }^{53}$, and even a casting of a Warsaw Ghetto Wall. ${ }^{54}$ These artifacts are deliberately included in the USHMM's permanent exhibition as evidence to support the museum's overarching Holocaust narrative.

Hansen-Glucklich discusses the idea of a "trace"; "a visible mark or object left behind that indicates the former presence of another object." 55 Such "traces" are uniquely able to bridge the gap in time, space, and circumstance between authentic versus artificial sites of memory. Both of these first two artifact categorizations may be considered traces. Furthermore, since the Holocaust did not occur on American soil, sites such as the USHMM are not technically authentic memory sites. However, the display of original artifacts in these places, combined with a cohesive rhetoric to contextualize those artifacts, makes it possible to bridge that gap.

There are a few items in the USHMM which fall somewhere between these two aforementioned categories, and can thus be given a third category of their own. I call these intermediate traces. One example is the casting of the path connecting the Treblinka killing

\footnotetext{
${ }^{50}$ See Appendix A, Figure 43.

${ }^{51}$ Williams, Memorial Museums, 28.

${ }^{52}$ See Appendix A, Figure 44.

${ }^{53}$ See Appendix A, Figure 47.

${ }^{54}$ See Appendix A, Figure 45.

${ }^{55}$ Hansen-Glucklich, Holocaust Memory Reframed, 127.
} 
center and the nearby forced-labor camp, ${ }^{56}$ located off to the side of the main path so as not to be walked over. Normally a path like this would be considered part of the second category; a mundane item given meaning through Holocaust contextualization, but in this case the road was cobbled not with ordinary stones, but with the crushed remains of Jewish cemetery headstones. On many of the largest pieces, Hebrew letters are still visible. The very existence of this path is violent, which lends it an element of that first category; the physical remnants of violence.

Section III: Photos and Videos as Evidence

Photographs are their own separate category of artifact, and Williams proceeds to divide them even further into subcategories.$^{57}$ First, action shots are typically violent images used as evidence of the occurrence of an event and may include candid shots of soldiers or inmates, purposeful photographs of torture, or even photographs of camp liberation. One noteworthy example of this kind of evidence from the USHMM is actually placed at the very start of the permanent exhibit, to be seen directly as one exits the elevator. It is an enlarged photograph of what appears to be a large pile of charred remains. Full charred bodies can be seen, along with logs and bits of rubble, all charred as if someone meant to conceal these crimes by burning them. And around this pile stand helpless soldiers, with hands stuffed into pockets or dangling uselessly by their sides. The soldiers are presumably Allied forces, and judging by the context of the museum, they are presumably US soldiers, standing powerlessly and astonished at the sight they are witnessing. ${ }^{58}$ As they were witnesses, so do we as onlookers become a kind of secondary witness, as viewers of this graphic, photographic evidence.

\footnotetext{
${ }^{56}$ See Appendix A, Figures 58 and 59.

${ }^{57}$ Williams, Memorial Museums, 51.

${ }^{58}$ See Appendix A, Figure 13.
} 
The second category under which photographs may fall is an image of identification. ${ }^{59}$ These photographs do not depict any overt violence, but their inclusion in a memorial context lends a certain feeling of uncanniness to the act of witnessing them. Examples of this type of photograph may include headshots used to identify the dead, eerie photos from a time before violence, with the photograph itself being the only clear remnant of its unknown or missing subject. Two examples in the USHMM are the two photo galleries; the Roman Vishniac collection ${ }^{60}$ and the "Tower of Faces" ${ }^{\prime \prime 1}$ exhibit. Both collections contain photographs taken of Jewish subjects before the Holocaust.

I would again propose a third category under which photographs may fall, within a memorial setting such as a museum - a category of memorial photography I call "intermediate photographs." This category describes a kind of in-between status, because these photographs contain qualities from both previous categories. Examples of these kinds of photographs may be headshots, in which the act of photographing would not have taken place outside of the conditions of violence, which also makes them a kind of action shot. In other words, their very existence can be used as evidence for violence, though they do not, themselves, depict violent acts. An example of this might be the USHMM's candid, colorized photograph of two women just walking down the street, one of whom has a bright yellow "Jude" star pinned to her coat, indicating that she is Jewish. ${ }^{62}$ This photo is not in itself inherently violent, but nonetheless serves as evidence of a violent and oppressive system under which race and religion were key distinguishing factors about a given individual. Another example of this kind of photograph may include the USHMM collection of photographs displaying the prison number arm tattoos of

\footnotetext{
${ }^{59}$ Williams, Memorial Museums, 63-64.

${ }^{60}$ See Appendix A, Figures 29-36.

${ }^{61}$ See Appendix A, Figures 37-40, 67, and 68.

${ }^{62}$ See Appendix A, Figure 42.
} 
former camp inmates.$^{63}$ These photos give no indication of who the people are; it does not show their faces, bodies, or any identifying factors besides the arm with the visible number tattoo. While a photograph of someone's arm or of someone's tattoo is not inherently violent, in this case, given the correct context, these photos are hard evidence of a violent and dehumanizing series of events, and of a corrupt system which fostered the violence.

A fourth subcategory of memorial photography is video footage. It may be subdivided into very similar categories as photographs may. "Action shots" as video footage may include things like footage of violence, or even post-violence or aftermath footage. "Identification" videos may be candid videos of subjects before violence has occurred and may be viewed in a similar fashion as identification photographs. If anything, these kinds of identification videos are even more unsettling than are their photographic counterparts, for one may see in them in real time being lived, a moment which lasts far longer than the eternity encased within a single photograph. Third, as an intermediate category, there exists an abundance of video footage of relatively nonviolent things like Nazi rallies, salutes to Hitler and other such "official" videos of the Nazi regime. Without proper context, these videos are seemingly not evidence of violence and can thus not be counted among the action shots - they are only violent when contextualized. They show evidence of a corrupt system, to be sure, but only when they are viewed with enough background information.

Section IV: The Nuances of Photographic Evidence

One important aspect of photography which can easily be overlooked is the photographer. Who has taken the photograph, or shot the video? In speaking about violent images, specifically

${ }^{63}$ See Appendix A, Figure 64. 
of synagogues desecrated during Kristallnacht, Dr. Janet Jacobs discusses how the repeated use of shocking images "[erases] the human element of violence". ${ }^{44}$ Images of torture or of people in pain often leave the perpetrators out of the picture. For example, that very first photograph shown in the USHMM depicts the aftermath of a crime, with no perpetrators in sight. In the case of this and of other photographs, shouldn't it matter who is taking the photo, and why it is being taken? Could that information not also serve as a kind of evidence in itself? For example, the very fact that images exist which depict human suffering and which were taken by the perpetrators of said suffering, serve as evidence of the near-inhuman nature of perpetrator complicity in these acts of terror. Several photographs on display in the USHMM simply state that they came from the National Archives in Washington, DC, without giving any indication of who took the photographs.

Hansen-Glucklich further discusses the danger which accompanies the "repeated reproduction and exposure of certain Holocaust images, which can lead to the loss of their referential efficacy". ${ }^{65}$ According to her, the repeated use of certain overused images in regards to Holocaust memorialization can lead to the photographs themselves becoming symbols of violence, rather than mere references to that violence. ${ }^{66}$ In other words, these often-reproduced, famous photos become an object of remembrance in their own right, rather than simple evidence, or "vehicles for the remembrance of the represented events." ${ }^{67}$ Such a simplification makes the acts of commemoration and remembrance quicker and simpler, but also causes these acts to lose their complexities. As a result, after repeated exposure to the same Holocaust photographs, viewers become less and less likely with each viewing to engage in a struggle with their own

${ }^{64}$ Jacobs, Janet. "Memorializing the Sacred: Kristallnacht in German National Memory." Journal for the Scientific Study of Religion 47, no. 3, 2008, 489.

${ }^{65}$ Hansen-Glucklich, Holocaust Memory Reframed, 13.

${ }^{66}$ Ibid.

${ }^{67}$ Ibid. 
ideas of the past, and therefore less likely to take something of value from each interaction with it. Xanthi Tsiftsi discusses the potential for the overexposure of images of human suffering to lead to the revictimization of victims in her article entitled "Libeskind and the Holocaust Metanarrative: from Discourse to Architecture" ${ }^{68}$ She discusses the idea of the Holocaust being "turned... into pornography," as stated by Israeli media in $2002 .{ }^{69}$ This term, "pornography," when used in a Holocaust context, describes "the reduction of human beings to commodities and the exposure of vulnerable people at the moment of their most profound suffering, hence re-victimizing the victims." 70

Section V: The Implications and Functions of Artifacts at the USHMM

Williams' first category of artifacts includes those which were produced by the perpetrators. $^{71}$ These items are among the most unsettling of all the artifacts on display. However, they cause discomfort primarily because of the way in which the museum has contextualized them rhetorically. Without this contextualization, these items might seem confusing, or even mundane. It is through the USHMM's use of rhetoric that they become violent and unsettling. ${ }^{72}$ One prominent example of a perpetrator-produced artifact is the USHMM's collection of Zyklon-B canisters. ${ }^{73}$ Zyklon-B was the chemical used to gas death camp prisoners toward the end of the Holocaust. They look similar to some kind of gas or propane can, so upon first seeing them outside of a museum context, one might not think much of them. But the context of their

${ }^{68}$ Tsiftsi, Xanthi. "Libeskind and the Holocaust Metanarrative; from Discourse to Architecture." Open Cultural Studies 1, no. 1, 2017, 299.

${ }^{69}$ Ibid.

${ }^{70}$ Ibid.

${ }^{71}$ Williams, Memorial Museums, 25.

72 Bernard-Donals, Figures of Memory, 59.

${ }^{73}$ See Appendix A, Figure 57. 
presence within the museum turns those canisters from slightly vague items reminiscent of gas cans, to eerie and sinister symbols of mass murder. Another example of a perpetrator-produced item is the USHMM's gold "Jude" star ${ }^{74}$, on display in the section discussing the ghettos in which Jews were forced to live. There isn't a context in which differentiating a minority group and forcing them to identify themselves as such is not sinister, and the simple language describing the item, combined with the context of the museum as a whole brings items like these to a new level of unsettling.

The second category of artifacts includes mundane items which are made eerie by contextualization. In other circumstances, an old twisted tree stump wouldn't generally be a startling sight. However, when that tree trunk is placed behind glass in a Holocaust museum and described as a mass grave marker, it suddenly takes on a new, sinister meaning. ${ }^{75}$ In another museum, the floor changing from concrete to cobblestones might be odd, but barely noticeable. However, when placed into a Holocaust museum and given a plaque which describes a cobblestone street in the Chłodna Jewish Ghetto, these stones under one’s very feet take on new meaning. ${ }^{76}$

In addition to an abundance of authentic artifacts, the USHMM also displays many replicas made from castings of Holocaust objects, most of which fall under that second category. One example is the replica of the Chłodna Street Ghetto cobblestones ${ }^{77}$, reassembled into a main pathway people must cross as a part of the main exhibition. Other examples include castings of the Warsaw Ghetto wall ${ }^{78}$, the Łódź Ghetto Hospital Doors ${ }^{79}$, the Tarnów Cemetery Gate ${ }^{80}$, and a

\footnotetext{
${ }^{74}$ See Appendix A, Figure 41.

${ }^{75}$ See Appendix A, Figures 27 and 28.

${ }^{76}$ See Appendix A, Figure 44.

${ }^{77}$ See Appendix A, Figure 44.

${ }^{78}$ See Appendix A, Figure 45.

${ }^{79}$ See Appendix A, Figure 46.

${ }^{80}$ See Appendix A, Figure 47.
} 
memorial wall made of fragments of Remu synagogue cemetery tombstones in Cracow. ${ }^{81}$ Replicas such as these were commissioned with the permission of the cities and countries in which the originals were located, and then painted and made to look more "dirty" to better fit the museum's narrative. ${ }^{82}$

The USHMM sought to honor and memorialize victims of the twentieth-century European Holocaust, while simultaneously seeking to educate contemporary audiences about the events that transpired. ${ }^{83}$ The museum's planning team decided that the best way to achieve both goals would be to focus on engineering 'authenticity'; to seek to achieve authentic responses by visitors to the information they were receiving. They also sought to achieve these goals without running the risk of oversimplifying the complex events they wanted to memorialize and analyze. They ultimately wanted to 'prove' that the events in question had happened, memorialize victims, and create an environment encouraging visitors to feel something, and to act on those feelings. The USHMM recognized the United States' existing collective narrative surrounding the Holocaust, and sought to shape and broaden this narrative within the minds of contemporary, primarily American viewers, into a more complete and complex understanding. ${ }^{84}$

In order to engender visceral responses from visitors, the USHMM carefully selected artifacts according to certain criteria, only selecting items which would serve as evidence to support the museum's Holocaust story. ${ }^{85}$ It was important that the raw, empathetic responses to the museum come primarily from the museum's rhetorical narrative, rather than from some inherent quality of the artifacts themselves. The USHMM also knew the importance of incorporating artifacts, including photographic evidence and video footage, into the museum's

\footnotetext{
${ }^{81}$ See Appendix A, Figures 69 and 70.

${ }^{82}$ Bernard-Donals, Figures of Memory, 61.

${ }^{83}$ Bernard-Donals, Figures of Memory, 49-53.

${ }^{84}$ Ibid., 9-10.

${ }^{85}$ Ibid., 59-65.
} 
permanent exhibition, which would purposefully disturb visitors. A careful balance between these more violent or disturbing objects, and less shocking alternatives was also an important part of authenticity for the USHMM. ${ }^{86}$

In order to achieve their goals regarding authenticity, the USHMM sought to include as much true information about the Holocaust as possible. ${ }^{87}$ In so doing, they, perhaps inadvertently, viewed the events in question through a primarily American lens, favoring traditional American values as the antithesis of twentieth-century German fascism. As a means of making sure not to oversimplify the Holocaust narrative, the USHMM's planning council decided to deliberately avoid a "happy conclusion" to the story, or indeed, any kind of conclusion at all. ${ }^{88}$ To this end, the "Hall of Remembrance" was designed - a final monument that inadvertently cements the USHMM's oversimplification of the Holocaust narrative more than anything else, placing US soldiers and Holocaust victims in solidarity as victims and heroes. The process of oversimplifying the Holocaust through the establishment of a too-cohesive narrative is futher reinforced by the physical and sensorial devices used to frame the artifacts within the permanent exhibition. I discuss these devices in further detail in Chapter Two.

\footnotetext{
${ }^{86}$ Bernard-Donals, Figures of Memory, 64-65.

${ }^{87}$ Hansen-Glucklich, Holocaust Memory Reframed, 77.

${ }^{88}$ Bernard-Donals, Figures of Memory, 65.
} 


\section{Chapter Two: Framing Devices}

In this chapter I discuss framing devices, which ultimately play a large role in determining a memorial museum's narrative. ${ }^{89}$ In the case of the USHMM, its framing methods pull together the intended narrative, incorporating artifacts into its story. In this chapter, I discuss different types of tangible display methods in memorial museums, such as certain architecture, lighting, artifact placement, physical informational signs, and other physical framing techniques. I also give examples of how these techniques were employed by the USHMM, and the kind of effects which are produced by these methods. Physical framing devices like these are generally intentional in places like a memorial museum, and can even be seen in the very architecture of the building itself. I also discuss techniques in framing exhibitions as they are seen in other Holocaust memorial museums, such as in Daniel Libeskind's Jewish Museum Berlin. In this chapter I also discuss intangible, or sensorial, framing devices which might be employed in memorial museums, which include things like the location of the museum, temperature, sound, smell, empty space, and other similar techniques. These sensorial framing methods are often layered on top of the built forms, to intensify visitors' capacities for emotional response.

Conversely, framing devices can also be used to disrupt that cohesive narrative, as is the case with Libeskind's Jewish Museum.

In the case of a memorial museum, actual, physical architecture is one of the most important framing elements that can be employed in order to promote a specific message. ${ }^{90}$ In the case of Holocaust Memorial Museums, most employ architecture in a purposeful way, which is related to each specific culture's ideology surrounding Holocaust memorialization. Architecture of memorial museums is important because it is responsible for framing artifacts within the

\footnotetext{
${ }^{89}$ Hansen-Glucklich, Holocaust Memory Reframed, 29.

${ }^{90}$ Ibid., 27-29.
} 
museum's narrative, and thus can significantly affect the visitor experience. According to architectural critic Michaela Giebelhausen, "the architecture is the museum: it is precisely the architectural configuration that gives the museum meaning... It not only frames the exhibits but also shapes our visitor experience." ${ }^{91}$

In the case of the USHMM, the architecture intentionally consists of concentration camp iconography, with stone pillars, shapes that resemble guard towers and chimneys, fences, and barbed wire. ${ }^{92}$ Even the lighting is uncanny, with strange shadows cast by pillars and too-little light barely brightening dark concrete walls. For example, at the end of the permanent exhibition, visitors must travel down the stairs into an eerily-lit, spacious area to be redirected to the exits, restrooms, and gift shop. The only noticeable artificial light in this space comes from dim floor lights, but the majority of the light is from the large skylights along the ceiling, which have iron bars crisscrossing them like barbed wire. ${ }^{93} \mathrm{I}$ also distinctly remember the elevators from my visit because to me they are eerily reminiscent of the crematorium ovens, with brick arches and steel doors. ${ }^{94}$ This was intentional: USHMM architect James Ingo Freed sought to make the "container one with the contained," by combining architectural tropes from ghettos and death camps with the postmodern facade of Washington's "empire of reason" architecture..$^{95}$ It is eerie how fluidly these two seemingly oppositional lines of architecture fit into one cohesive building. The structure does indeed fit nearly seamlessly with much of the architecture found along Washington D.C 's landscape, while simultaneously being uncomfortably reminiscent of the architecture seen in so many photographs and footage taken from the death camps and ghettos of twentieth- century Europe.

${ }^{91}$ Giebelhausen, quoted in Hansen-Glucklich, Holocaust Memory Reframed, 29.

${ }^{92}$ Hansen-Glucklich, Holocaust Memory Reframed, 76.

${ }^{93}$ See Appendix A, Figure 7.

${ }^{94}$ See Appendix A, Figure 8.

${ }^{95}$ Hansen-Glucklich, Holocaust Memory Reframed, 76. 
While the USHMM was designed with both a Washingtonian facade and concentration camp iconography in mind, this is not the only feasible approach a Holocaust-themed memorial museum may take. Daniel Libeskind is an architect known for his architectural deconstructivism, the most famous example of which is his Jewish Museum Berlin. ${ }^{96}$ One of Libeskind's goals is to use architecture to appeal to human emotion. He does not necessarily seek a specific reaction from visitors, but rather he seeks to use an architecture focused on absence and void to make visitors feel out of place and uncomfortable, perhaps without knowing why. ${ }^{97}$ Libeskind's physical and implied architecture contributes to the overall narrative of the museum, or, perhaps, to the poignant and intentional lack thereof. This architecture is a contrast to that of the USHMM, which seeks, through architecture, to reinforce an already pre-established narrative. Hansen-Glucklich sees memorial museum architecture as a display of some idea of the sacred; each of the three museums she studied sought to represent what was sacred to them in a unique way. ${ }^{98}$ For the USHMM, the "sacred," almost religious message being reiterated was one praising American values as the antithesis of German fascism. ${ }^{99}$ In her perspective, architecture is one of the most important framing devices a museum can have, because it ties together the overall message the museum seeks to present, directly shaping visitors' emotional responses to the museum, and, ultimately, to the Holocaust as a whole. ${ }^{100}$

Interior framing devices, including display cases, artifact and rhetoric placement, and the movement of the permanent exhibition as a whole, also play a role in reinforcing the museum's message. ${ }^{101}$ Different framing devices inside the walls of the USHMM have different purposes

\footnotetext{
96 Tsiftsi, "Libeskind and the Holocaust Metanarrative", 293-294.

${ }^{97}$ Hansen-Glucklich, Holocaust Memory Reframed, 31.

98 Ibid., 27.

99 Ibid., 77.

${ }^{100}$ Ibid., 29.

${ }^{101}$ Ibid., 123.
} 
and thus produce different visitor responses. For example, the museum's architecture is intentionally built to conceal some of the more graphic images from younger visitors, with concrete barriers reserving the display of these photographs for more mature audiences. ${ }^{102}$ This ensures that visitors are not forced into a potentially overwhelming experience for which they might not be prepared. Another example is the open rail car, ${ }^{103}$ placed with doors open obstructing the path so that visitors must walk through it, and the Chłodna Street Ghetto cobblestones, ${ }^{104}$ which make up part of the exhibit and which must be walked over. By placing these artifacts in this manner, the USHMM is forcing its visitors to experience them in a very real way; visitors are encouraged, by the placement of these artifacts, to put themselves very viscerally in the shoes of others who walked the same path or who occupied a similar space. This is one of the most direct ways the USHMM attempts to bridge the gap of time and space, compelling visitors to become witnesses of the past.

One thing the USHMM places great emphasis on through interior framing methods, are items of religious, specifically Jewish, significance. The well-lit case of partially ripped and burned Torah scrolls ${ }^{105}$ is displayed prominently in the center of a room. This prominently-placed display is surrounded by rhetoric describing Kristallnacht, the night of November 9th, 1938, when Nazis and others simultaneously broke into Jewish businesses, homes, and synagogues across the country, destroying property and wreaking havoc. Near the display of Torah scrolls stands what is known as a Torah ark, from a synagogue, encased in glass. ${ }^{106}$ The Hebrew words on the arch have been gouged and stabbed at and are all but unreadable, but a translation is posted on a nearby informational plaque: "Know before whom you stand."

\footnotetext{
${ }^{102}$ See Appendix A, Figures 49 and 50.

${ }^{103}$ See Appendix A, Figure 43.

${ }^{104}$ See Appendix A, Figure 44.

${ }^{105}$ See Appendix A, Figure 24.

${ }^{106}$ See Appendix A, Figures 25 and 26.
} 
It is no coincidence that a large photograph of Adolf Hitler is deliberately placed off to the side and behind iron bars that stretch across the wall. ${ }^{107}$ Behind those same bars hangs a red Nazi flag. ${ }^{108}$ This placement is purposeful: it is a way for the museum to clearly and deliberately relegate Hitler and the Nazi flag to the sidelines and throw him and all he stands for into prison, complete with iron bars. Simultaneously, in displaying these items in this way, the USHMM is taking a clear stance on Hitler and his values.

Another very direct way in which visitors are invited to interact with the past is through the use of handouts full of rhetoric. While there is no actual tour, visitors are gathered to the elevators and given an "identification card," 109 before being sent up the elevators to begin the self-guided tour through the permanent exhibition. This identification card is a little paper booklet about the size of a US passport, and, like the passport, the United States' seal is featured on the cover. However, instead of the famous latin words, "E pluribus unum," which are featured on the passport, this identification card reads, wrapping around the seal, "For the dead and the living we must bear witness." Inside, visitors will find that their card matches with the name, photograph, and information about a real person who lived during the Holocaust. Different pages hold different bits of information, and the last page tells of that person's fate. The back cover describes where more information can be found. Furthermore, the very back side of this booklet discusses some of the aims of the USHMM: to "inspire citizens and leaders worldwide to confront hatred, prevent genocide, and promote human dignity."

Another prominent display is the Shtetl Photo gallery, called the "Tower of Faces." ${ }^{110}$ It is situated on two separate floors. First, visitors experience it toward the beginning of the

\footnotetext{
${ }^{107}$ See Appendix A, Figure 22.

${ }^{108}$ See Appendix A, Figure 23.

${ }^{109}$ See Appendix A, Figures 10, 11, and 12.

${ }^{110}$ See Appendix A, Figures 37-40.
} 
permanent exhibition, when they've only just begun to learn about the horrors of the Holocaust. At that time, there is a surprising amount of photographs, which disappear below the feet and ascend up to a well-lit, bright ceiling. The beginnings of an understanding of the past tinges the photo gallery with sadness, and it isn't until nearly the end of the permanent exhibit that it must once again be walked through, this time on the lower floor beneath the bridge. ${ }^{111}$ However, the second time the gallery is walked through, it is darker, and, looking up, photos can be seen disappearing out of sight beyond the metal grate-like footbridge of the floor above. This time, the gallery is experienced after visitors have learned about the methodization of mass murder, after they have learned about the killing and disposal of bodies, and after they have just witnessed for themselves the meager physical imprint left behind by hundreds of thousands of victims. When considered in this context and with this reiterated historical knowledge, the number of photographs is not just surprising, it is staggering.

One very poignant, often-discussed display by the USHMM is its nearly total lack of framing of the pile of shoes ${ }^{112}$ recovered from death camps. This gap is purposeful; it prompts visitors to "first feel and then consider" what they are witnessing. ${ }^{113}$ As visitors first come upon the display, the smell of decaying leather is noticeable, and the sheer volume of shoes is staggering. Visitors must walk over a bridge, looking to the left, to the right, and down below their feet at the mountainous pile of different-sized shoes. Over time the shoes have decayed to a brown sameness, and, over time, they have become more difficult to differentiate. The display is uncanny, and is eerily reminiscent of the piles of human remains depicted in several famous Holocaust photographs. A quote ${ }^{114}$ is displayed on the wall above the shoes, and the opposite

\footnotetext{
${ }^{111}$ See Appendix A, Figures 67 and 68.

${ }^{112}$ See Appendix A, Figures 62 and 63.

${ }^{113}$ Hansen-Glucklich, Holocaust Memory Reframed, 131.

${ }^{114}$ See Appendix A, Figure 63.
} 
wall shares the same quote, but in Hebrew letters. It is a poem written by Yiddish poet Moses Schulstein:

We are the shoes, we are the last witnesses.

We are shoes from grandchildren and grandfathers

From Prague, Paris, and Amsterdam.

And because we are only made of fabric and leather -

and not of blood and flesh - each one of us

avoided the hellfire.

As is the case with the display of shoes in the USHMM, sensorial framing methods, like smell, are often layered on top of the built forms, to intensify visitors' capacities for emotional response. This kind of sensorial technique employs the use of sound, smell, empty space, temperature, as well as several more subtle factors, to tell the museum's story. Even the museum site's location and history may contribute to its framing methods. ${ }^{115}$ Methods of artifact display come in a variety of physical forms, and these framing devices are built the way they are in order to convey an intangible message.

Another interesting framing device employed by the USHMM was the inclusion of an auditory exhibit called "Voices from Auschwitz", located in a separate room off to the side of the rest of the exhibit. ${ }^{116}$ Though visitors didn't have to go through "Voices from Auschwitz" as part of the main exhibition, if they chose to do so they would enter the glass room, sit down, and be encompassed by auditory survivor testimony, played from several speakers strategically placed throughout the room. It was a deliberate choice to frame this auditory evidence in such a fashion.

\footnotetext{
${ }^{115}$ Williams, Memorial Museums, 77-78. ${ }^{116}$ See Appendix A, Figures 60 and 61.
} 
The glass walls allowed one to be in an enclosed space, surrounded by witness testimony, cut off from other visitors, yet still able to see them. I sat in there and, with my eyes closed, I felt transported to another place, where I was in the presence of Holocaust witnesses and survivors. When my eyes opened, I could see other visitors continuing on outside the room as usual. That might be the closest I'll ever come to bridging the gap between myself and those witnesses. When survivors escaped that nightmare and were expected to move on, to live life as usual, there must surely have been times they felt trapped behind glass surrounded by their own trauma, seeing the world carry on as if behind a window.

Why was this part of the exhibit set off to the side? I believe the answer is more complex than the question. The USHMM could have placed this display in the middle of the path, trapping visitors in the room and forcing them to listen to this auditory testimony in order to pass into the next part of the exhibition. Or, they could have centered a similar glass box in the middle of a room - small enough still to opt out of the experience, but large enough to get a similar fishbowl effect. However, I think that the way in which it was done accomplishes a complex goal. First, by locating "Voices from Auschwitz" in a place off to the side, where entry was optional, the USHMM made sure not to force visitors into a potentially difficult or overwhelming experience, similar to what they accomplished with hiding explicit images behind stone barriers to censor less mature viewers. Second, this choice to place the experience off to the side was surely intentional; it gave implicit permission for unprepared visitors to choose not to participate, while simultaneously producing the phenomenon of sitting behind the glass watching people and remaining relatively unnoticed, as I mentioned in my experience. An additional clue to the placement of these survivor testimonies lies in the opinion shared by many scholars that testimony is inherently unreliable, as it is heavily shaped by the time period - and 
the discourses popular at that time - in which it was given. ${ }^{117}$ Perhaps the museum sought to distance itself from this potentially flawed form of evidence, more solidly relying upon physical objects to tell what seemed to be a more factual story.

Framing devices within memorial museums, such as architecture, interior display choices, and sensorial devices, are important for the framing of the museum's overall narrative. ${ }^{118}$ Especially in the USHMM's case, these framing methods are as important to the sustaining of its overall Holocaust narrative as are artifacts themselves. In the USHMM, the almost reverent promotion of American values as the antithesis of genocide and dictatorship shines through in its framing choices. In its deliberate and strategic placement of artifacts throughout the permanent exhibition, the USHMM attempts to encourage its visitors to "experience" the past; to bridge the gap in time and space by becoming secondary witnesses to the Holocaust. ${ }^{119}$ By choosing which artifacts to explicitly frame, and which, as with the shoe display, not to frame, the USHMM is able to direct visitors toward a particular narrative and memory of the past, while maintaining the appearance of an unbiased archive of information.

\footnotetext{
${ }^{117}$ Wieviorka, The Era of the Witness, xii.

${ }^{118}$ Hansen-Glucklich, Holocaust Memory Reframed, 27-29.

${ }^{119}$ Ibid., 132-134.
} 


\section{Chapter Three: Collective Memory}

Collective Memory is a term that was coined by Maurice Halbwachs in the early to mid-twentieth century, and has since been debated and discussed extensively by many experts. ${ }^{120}$ Bernard-Donals posits this definition: "Cultural or public memories are typically agreed-upon representations of past events that serve to forge a collective identity among individuals in a community." ${ }^{212}$ Halbwachs states that we, as individuals, "acquire, recall, reorganize, and localize" our memories only within the context of societies. ${ }^{122}$ We recall memories through external prompts, and any discourse or idea that we might have based on our lived experiences is shaped by our own socialization within the society in which we live. Individuals are, of course, uniquely capable of independent thought but individuals also, according to Halbwachs, cannot discuss opinions or ideas without the impact of social thought. Additionally, especially in the case of a traumatic event like the Holocaust, recent lived memories and experiences within a society exist in a relatively collective sense because they are "part of a totality of thoughts common to a group." 123 Thus, a kind of collective memory will always exist within any given community, because of the very nature of societies as collective units which shape individual perception of events.

In the 1960s, TV shows and films began to be developed depicting the Holocaust. One such show,entitled Holocaust, depicted two mid-twentieth century German families; one an assimilated Ashkenazi Jewish family, and the other a German family won over to Naziism. ${ }^{124}$

\footnotetext{
${ }^{120}$ Halbwachs, Maurice. On Collective Memory. Translated by Lewis A. Coser. Chicago, IL: University of Chicago Press, 1992, 38.

${ }^{121}$ Bernard-Donals, Figures of Memory, 9.

${ }^{122}$ Halbwachs, On Collective Memory, 38.

${ }^{123}$ Ibid., 52.

${ }^{124}$ Wieviorka, The Era of the Witness, 99.
} 
The show was met with serious backlash from Holocaust survivors, who were angry both about the show's oversimplification of characters into romantic clichés and about its avoidance of showing any of the "real" suffering and violence faced by Holocaust victims. They were frustrated that this show, meant to encapsulate a portion of the horror they endured and share their stories with the world, was simply another 'Hollywood product,' full of classic Hollywood scenes like the separation of lovers or the death of a family member. Themes which witnesses knew really characterized the history of the Holocaust such as "intolerable anguish, suffering, hunger, mass death" were missing. ${ }^{125}$ The response from many such survivors was a cry of "so many lost their lives; will their stories be taken away too?"'126 According to Dr. Annette Wieviorka in her book, translated into English, entitled The Era of the Witness, it wasn't so much that survivors hoped to find their suffering easily encapsulated by the depiction of a single Jewish family in the media; that would have been an unrealistic expectation. But the choice of "the assimilated Jew from the Western European petit bourgeoisie" was not random. ${ }^{127}$ According to Wieviorka, "it was... easier for the US viewer to identify with this type of person than with a Polish Jew wearing a caftan and sidelocks, the father of a large, Yiddish-speaking family." 128

According to Wieviorka, dramatizations such as these led to a collective memory of the Holocaust in the United States in the 1960s, which favored certain tropes and caricatures over others, and didn't have room for other kinds of testimony. However, ultimately the backlash against this reiterated American narrative about the past was finally heard, after so many victims

\footnotetext{
${ }^{125}$ Wieviorka, The Era of the Witness, 99-100.

${ }^{126}$ Ibid., 100.

${ }^{127}$ Ibid., 101.

${ }^{128}$ Ibid.
} 
spoke up. One such witness was writer Elie Wiesel, who declared, "the witness feels here duty-bound to declare: what you have seen on the screen is not what happened there." 129

A month after the broadcast of Holocaust, a presidential Holocaust Commission was formed in the US, headed by Wiesel, who had become the face of Holocaust survivors in the US. ${ }^{130}$ The Eichmann trial of 1961 then brought witness testimony back into the spotlight, and Holocaust survivors felt compelled once more to speak up about their experiences. Collective memory can be established and reinforced by a number of factors, one of which is survivor testimony. ${ }^{131}$ According to Wieviorka, testimony is inherently unreliable because it is shaped by the views and discourses of the society and era in which it is given. Subsequently, testimonies given tend to nicely fit in with the collective memory of the event which exists at the moment the testimony is being shared, and is thus sometimes treated by historians with inherent mistrust. In other words, Wieviorka agrees with Halbwachs' idea that any individual discourse, in this case specifically anecdotal discourse, must inherently be shaped by the society in which it is given. This coincides with the moment in the 1960s and 1970s when societies slowly began to be measured based on their treatment of issues of human rights. ${ }^{132}$ This made the "individual" representative of the "public embodiment of history," retroactively placing this idea of the "individual" at the forefront of history as a whole. ${ }^{133}$

In The Generation of Postmemory: Writing and Visual Culture After the Holocaust, Marianne Hirsch defines what she calls postmemory, a phenomenon related to the intergenerational passing down of trauma. ${ }^{134}$ A child of Holocaust survivors herself, Hirsch

\footnotetext{
${ }^{129}$ Wiesel, quoted in Wieviorka, The Era of the Witness, 100.

${ }^{130}$ Ibid., 105.

${ }^{131}$ Wieviorka, The Era of the Witness, xii.

132 Ibid., 97.

${ }^{133}$ Ibid.

${ }^{134}$ Hirsch, The Generation of Postmemory, $1-6$.
} 
discusses the unique nature of her relationship with her parents' endured experiences during their lives. Critique of the notion of postmemory draws a line between history and memory, arguing that an outside, unlived experience cannot possibly have an inter- or transgenerational effect on those who have not lived through the experience themselves. Though postmemory doesn't technically refer to a true recall of others' experiences, (as the inclusion of the word "memory" in the name may at first denote,) Hirsch argues that it is nonetheless an appropriate term, due to its imitation of memory in both its affective force and in its psychic affect of the human subconscious. In Hirsch's words, postmemory is “a consequence of traumatic recall, but at a generation removed." 135 In the case of Hirsch and other members of her generation whose parents lived through the Holocaust, postmemory refers to both a symbolic relationship as well as a form of embodied experience with their parents' past and the inheritance of trauma. ${ }^{136}$ In the case of the Holocaust, Hirsch argues that the postmemory which exists among the second generation leads, even more strongly, to a Halbwachs-esque collective memory.

Hirsch goes on to discuss and analyze the various works on memory by Jan and Aleida Assmann. ${ }^{137}$ She agrees with the assessment that there are essentially two avenues of collective remembrance: both communicative and cultural remembrance. Communicative remembrance is biographical, factual evidence that exists within the memories and lived experiences of adult firsthand Holocaust witnesses. This kind of remembrance can be intergenerationally transmitted, through postmemory, for up to three or four more generations, and it is mediated through embodied experience. The desire by these early rememberers to institutionalize or immortalize these memories for future generations is what leads to a cultural remembrance.

\footnotetext{
${ }^{135}$ Hirsch, The Generation of Postmemory, 6.

${ }^{136}$ Ibid., 32-38.

${ }^{137}$ Ibid., $31-33$.
} 
Cultural remembrance consists of two subcategories: politically and culturally mediated remembrance. ${ }^{138}$ At this point of commemoration, the memory transmission is no longer intergenerational, but rather transgenerational, that is, transferable to individuals who do not share experiences with those who are part of this communicative collective memory. In other words, the transition from this private remembrance, applicable to first and second-generation rememberers, to a public one, transforms postmemory into collective memory. This new kind of cultural remembrance is then mediated through symbolic systems, rather than through embodied practice. This transition creates a "gap," between the embodied or experienced remembrance of postmemory, and the merely symbolic remembrance characteristic of collective, or cultural, memory. This gap is difficult to surmount, but memorial museums seek to overcome it anyway, by reinforcing more distant, symbolic memorial systems with elements of embodied practice, typically characteristic of communicative forms of remembrance.

It is, indeed, important for museums and other public memorial institutions to be aware of, and seek to combat, some of the negative repercussions associated with the reliance on collective memory to tell a particular history. To do this, museums must decide what kind of narrative to promote, and to what extent they are willing to disrupt the widely accepted collective narrative. However, some scholars question whether a collective narrative of any kind should ever be unquestionably accepted as true. Cullen Goldblatt, in his book Beyond Collective Memory: Structural Complicity and Future Freedoms in Senegalese and South African Narratives, postulates that "collective memory" itself is a problematic term. ${ }^{139}$ For him, one of the biggest dangers that can come from extending the idea of memory past a single mind is that

${ }^{138}$ Hirsch, The Generation of Postmemory, 33.

${ }^{139}$ Goldblatt, Cullen. "Introduction.” Introduction. In Beyond Collective Memory: Structural Complicity and Future Freedoms in Senegalese and South African Narratives, 1-30. New York, NY: Routledge, 2021, 4-5. 
doing so can oversimplify the past into a broad, digestible, and repeatable idea, which is, firstly, disrespectful to the complex figures at each level of that particular history. Furthermore, this oversimplification of memory also "obscures human agency in the making and telling of the past," which allows people to potentially overlook roles of complicity and structural corruption. This can be dangerous, especially if it is a government agency that is enforcing this singular "collective" narrative.

The presidential Holocaust Commission headed by Wiesel eventually gave way to the formation of the American Memorial Council of the Holocaust in 1980, charged with creating a national memorial to the Holocaust. This council eventually began work planning the USHMM, which opened in 1993. ${ }^{140}$ This planning council, according to Bernard-Donals, sought to shape the existing collective memory of the Holocaust within the United States into a more vivid and thorough understanding of both the Holocaust story in general, and, specifically, of Jewish victimization. ${ }^{141}$ One way they chose to do this was by instituting a careful balance between more and less violent artifacts, as well as implementing certain, specific framing methods to display these artifacts, in order to better establish their overarching narrative. In Bernard-Donals' eyes, the USHMM is thereby successful in moving and shaping memory in visitors, leading them to apply the uncomfortable feelings they experience at the museum to contemporary topics. ${ }^{142}$ One artifact type to which the USHMM paid extra attention was photography. In this, they are not alone. Hirsch discusses photography as one prominent method used by memorial museums as an attempt to bridge the gap between embodied and symbolic remembrance. ${ }^{143}$ I use Williams' categorizations again to analyze Hirsch's thoughts on photography. ${ }^{144}$

\footnotetext{
${ }^{140}$ Wieviorka, The Era of the Witness, 106-107.

${ }^{141}$ Bernard-Donals, Figures of Memory, 9-10.

${ }^{142}$ Ibid., 184.

${ }^{143}$ Hirsch, The Generation of Postmemory, 38.

${ }^{144}$ Williams, Memorial Museums, 51.
} 
First, action shots, or photographs acting as evidence of violence, serve also, according to Hirsch, to signify the past's "insurmountable distance." 145 They are so violent, and so foreign to contemporary audiences that they serve a strictly symbolic purpose in memorialization, highlighting the gap between the violent past and contemporary present. On the other hand, according to Hirsch, identification photos, and especially photographs containing much more familiar, familial aspects, serve to bridge this gap between the past and present, ultimately serving to reanimate memorialization. The familiarity of identification photos diminishes the perceived distance between past and contemporary witnesses, which had previously been made visible by action shots. Action shots are necessary for evidentiary purposes, but must be interspersed with more familiar identification photographs in order to bring the distant past back into contemporary relevance. Through this careful balance, photography is capable, according to Hirsch, of bringing embodied practice, characteristic of communicative remembrance, into cultural remembrance's archival memorialization. Thus, through a mixture of embodied practice and symbolic commemoration, memorial museums are able to carefully craft a collective narrative which will direct contemporary audiences toward a more thorough, sympathetic understanding of the past.

The USHMM addressed Hirsch's very concept involving the balance of photographic evidence in their 1988 document “A Working Response to the Question of Explicit Imagery Including 'The Pornography of Murder,' Nudity and Violence in a Museum." 146 This concept may also be applied both more generally to artifact selection, as well as to the framing devices themselves. The USHMM carefully considered which kinds of artifacts to use, and what kind of narrative would be supported by the chosen evidence. Their 1986 "Draft Collection Management

\footnotetext{
${ }^{145}$ Hirsch, The Generation of Postmemory, 38.

${ }^{146}$ Bernard-Donals, Figures of Memory, 64-65.
} 
Policy" confirms the USHMM's deliberate establishment of a cohesive Holocaust narrative, supported by artifacts and other memorialization techniques. ${ }^{147}$ In so doing, the USHMM relied on, first, the existence of collective memory, and, second, their manipulation of it, to guide visitors toward a more visceral, complete understanding of the Holocaust of the twentieth century. ${ }^{148}$ However, in so doing, the USHMM also falls directly into the traps against which Goldblatt warns. ${ }^{149}$ In establishing such a cohesive, seemingly comprehensive narrative, the USHMM in fact oversimplifies the complex events of the Holocaust into a simple story: Primarily white, Ashkenazi Jews were dehumanized and victimized by an inhuman, unfathomably evil group, which was subsequently fought and squarely beaten by Americans, who represent freedom, equality, and democracy. Furthermore, in establishing this singular narrative, the USHMM also fails to acknowledge the utterly mortal nature of all persons involved in the Holocaust. Victims weren't all passive, perpetrators weren't all violent racists. There were more than just two or three distinct groups involved in this past, because individual people are more complex than these oversimplified tropes would suggest. In the USHMM's establishing of this easily-summed up narrative, the response which naturally arises is, once more, "the witness feels here duty-bound to declare: what you have seen ... is not what happened there." $" 150$

${ }^{147}$ Bernard-Donals, Figures of Memory, 59.

${ }^{148}$ Ibid., 9-10.

${ }^{149}$ Goldblatt, Beyond Collective Memory, 5.

${ }^{150}$ Wieviorka,The Era of the Witness, 100. 
Conclusion

As has been made clear, the memorialization of past traumatic events such as the Holocaust is extremely nuanced. Many factors make up what makes a respectful and impactful museum, and there is no black and white answer as to how commemoration is best achieved. We, as individuals and as communities, need to learn how to best confront and recall past trauma, so that we will be enabled to deal with new trauma as it arises. The past, especially the dark past, must be constantly faced and recalled in a productive manner, because contemporary understanding can be exponentially enhanced by the past's continual perusal. We can learn so much from past experiences and mistakes.

The USHMM's planning committee decided that their goals of memorialization and education would best be met through the eliciting of empathetic reactions from visitors, which would lend authenticity to their Holocaust message. They recognized a collective memory already present in medial depictions of the Holocaust in the United States, and sought to avoid the oversimplification of that message. ${ }^{151}$ In that vein, the USHMM hoped to encourage the expansion of visitors' preconceived ideas about history, through the introduction of more information, and through the provocation of empathetic, visceral responses. ${ }^{152}$ By accepting, and not questioning, the collective Holocaust narrative already present within the United States, the USHMM, perhaps inadvertently, retained an American lens in their depictions of the past. Thus, the museum's overarching narrative has a definite bias toward the American values of democracy, freedom, pluralism, and individual rights. ${ }^{153}$

In a further effort to avoid the oversimplification of the narrative, the Hall of Remembrance was placed at the end of the permanent exhibition, as a way to avoid "happy

${ }_{151}$ Bernard-Donals, Figures of Memory, 49-53.

152 Ibid., 9-10.

${ }^{153}$ Hansen-Glucklich, Holocaust Memory Reframed, 77. 
conclusion" to the Holocaust story, or indeed, any kind of conclusion at all. ${ }^{154}$ The most prominent display in this spacious room is a large, black, tomb-like structure which claims to contain soil gathered "from death camps, concentration camps, sites of mass execution, and ghettos in Nazi-occupied Europe, and from cemeteries of American soldiers who fought and died to defeat Nazi Germany." Atop this tomb-like monument burns an eternal flame, reminiscent of that which burns at the Tomb of the Unknown Soldier, in Arlington National Cemetery.

One of the biggest questions in my mind as I encountered this monument and read its description was, "why is the soil from cemeteries of US soldiers mixed in with the soil from concentration camps, execution sites, and ghettos?" This final monument cements the USHMM's oversimplification of the Holocaust narrative more than anything else, placing US soldiers and Holocaust victims in solidarity as victims and heroes. By including the soil together, and with the inclusion of the very American symbol of an eternal flame, the USHMM is equating the demise of US soldiers with that of millions of dehumanized, murdered people. Though these soldiers were victims of the second world war, they were not victims of the Holocaust, which this museum claims to commemorate. In placing Holocaust victims figuratively in the same box as fallen American soldiers, the USHMM is solidifying the reduction of people into two-dimensional tropes. With this monument, the USHMM is saying, more explicitly than ever before, that the Holocaust story consists of three distinct groups: helpless victims, evil Nazi fascist oppressors, and brave American heroes. In this story, the heroes and victims are aligned in opposition to the evil oppressors.

Bearing all of the USHMM planning committee's intentions for the permanent exhibition in mind, it is also worth noting that the location and history of a memorial museum are also very

${ }^{154}$ Bernard-Donals, Figures of Memory, 65. 
important factors when discussing its resulting impact. ${ }^{155}$ As the USHMM today stands, it is located within the National Mall in Washington, D.C., which is a large area of parkland containing many of the United States' most significant memorials and symbols. ${ }^{156}$ Amid so many important symbols of American values, American tragedies, and American heroes, it naturally begs the question: why is a memorial for victims of a foreign war, which never reached American shores, located in the same place as so many symbols of American heroism? Is this, perhaps, an explanation for why such a significant part of the museum's Holocaust narrative relies on the upholding of American soldiers as beacons of American values instead of confronting genocide committed on American soil? The fact remains that this Holocaust museum opened in 1993- eleven years before the opening of Washington, D.C.'s National Museum of the American Indian, ${ }^{157}$ and twenty three years before the opening of the National Museum of African American History. ${ }^{158}$ This history alone indicates that the United States was more prepared to discuss the fault of other nations, painting itself as the hero, than it was to discuss horrors in which the US was the perpetrator. That the USHMM was built and dedicated before the national museums discussing American-perpetrated violence and genocide speaks volumes about a US approach to trauma and Vergangenheitsbewältigung. It is, unfortunately, not surprising that an American-made museum devoted to the Holocaust would promote American

\footnotetext{
${ }^{155}$ Williams, Memorial Museums, 77-78.

156 “History \& Culture.” National Parks Service. U.S. Department of the Interior. Accessed November 15, 2021.

157 "National Museum of the American Indian." Smithsonian Institution Archives. Smithsonian Institution Archives, April 14, 2011. https://siarchives.si.edu/history/national-museum-american-indian.

158 "Visiting the Smithsonian National Museum of African American History and Culture: Washington DC.” National Museum of African American History \& Culture | NMAAHC. Accessed November 29, 2021.

https://washington.org/visit-dc/guide-to-smithsonian-national-museum-african-american-historyculture\#.
} 
values like democracy, freedom, pluralism, and individual rights. ${ }^{159}$ But the United States went even further with this pursuit, and in 2004, still before the dedication of either the National Museum of the American Indian or the National Museum of African American History, the World War Two Memorial was dedicated in the National Mall in May of 2004. ${ }^{160}$ The description of the memorial from its official website reads, "Twenty-four bronze bas-relief panels flank the ceremonial entrance. To many, these panels stir memories as they tell the story of America's experience in the war. Granite columns representing each U.S. state and territory at the time of World War II ring an impressive pool with water shooting high into the air. Quotes, references to theaters, campaigns, and battles, and two massive victory pavilions chronicle the efforts Americans undertook to win the war. A wall of 4,048 gold stars reminds all of the supreme sacrifice made by over 400,000 Americans to make that victory possible." ${ }^{161}$

This second memorial in Washington, D.C. is another factor to consider when discussing the success of the USHMM, for the two memorials' close proximity to one another is unlikely a mistake. In discussing the major backlash accompanying the unveiling of this second memorial, one critic says, in reference to the WWII Memorial's grand stone architecture, "This is all stock celebration, not true commemoration - there's no true calling to mind of what the war meant, and then committing it to memory." ${ }^{162}$ In addressing these and other criticisms of the WWII Memorial, J. Carter Brown, chairman of the Washington Committee of Fine Arts, stated, "if triumphal arches and victory wreaths don't give you the sense that we won the war, I'm sorry."163

\footnotetext{
${ }^{159}$ Hansen-Glucklich, Holocaust Memory Reframed, 77.

160 "History \& Culture." https://www.nps.gov/wwii/learn/historyculture/index.htm. ${ }^{161}$ Ibid.

${ }^{162}$ Gopnik, Blake. "Many Words, Little Eloquence." The Washington Post. WP Company, May 23, 2004. https://www.washingtonpost.com/archive/lifestyle/style/2004/05/23/many-words-little-eloquence /9a7ddc40-3304-46ef-ae0f-447600cde4a0/.

${ }^{163}$ Brown, quoted in Williams, Memorial Museums, 2.
} 
This statement is quite telling about the way American involvement in the Second World War, and, by extension, the Holocaust, is viewed.

The United States as a country still suffers from racism and prejudice to this day-and, as Hansen-Glucklich posits, this fact alone questions, or even undermines, the very value of the museum as a memorial to victims of the Holocaust. ${ }^{164}$ To this end, at the opening ceremonies of the USHMM, during his speech, Elie Wiesel took the opportunity to confront then-president Bill Clinton about the then newly independent nation of Bosnia-Herzegovina, deeply entangled in a war with Serbia: “As a Jew, I am saying we must do something to stop the bloodshed in that country. People fight each other and children die. Why? Something must be done." ${ }^{65}$ Wiesel's confrontation of the president echoes a common belief among Holocaust rememberers and scholars; that seeing the representation of past traumatic events, and bringing these into context with contemporary events, "should lead a person to do something."

Today, in 2021, Americans are living through a historical reckoning. We are beginning to step up and talk about our country's violent past, and we are calling into question the way our government and media depict events that this nation perpetrated. Statues and monuments are being defaced and torn down, and Wiesel's ideas about memorialization and discussion of the past are coming into ever sharper focus; learning these things should lead us to do something. The USHMM is an important archive of Holocaust objects, but in terms of its narrative and the way in which these objects are presented, it falls short of making visitors feel like they need to change their lives upon leaving. As I consider the USHMM in its entirety, one solitary thought, a question, sticks out in my mind. So, I join my voice with the voices of the witnesses, and ask, "so many lost their lives; will their stories be taken away too?"166

\footnotetext{
${ }^{164}$ Hansen-Glucklich, Holocaust Memory Reframed, 218.

${ }^{165}$ Bernard-Donals, Figures of Memory, 155- 156.

${ }^{166}$ Wieviorka, The Era of the Witness, 100.
} 
Appendix A:

\begin{tabular}{|c|c|}
\hline Figure 1: & \begin{tabular}{c} 
Internal architecture in the USHMM \\
\hline
\end{tabular} \\
\hline Figure 2: \\
\hline \\
\hline
\end{tabular}




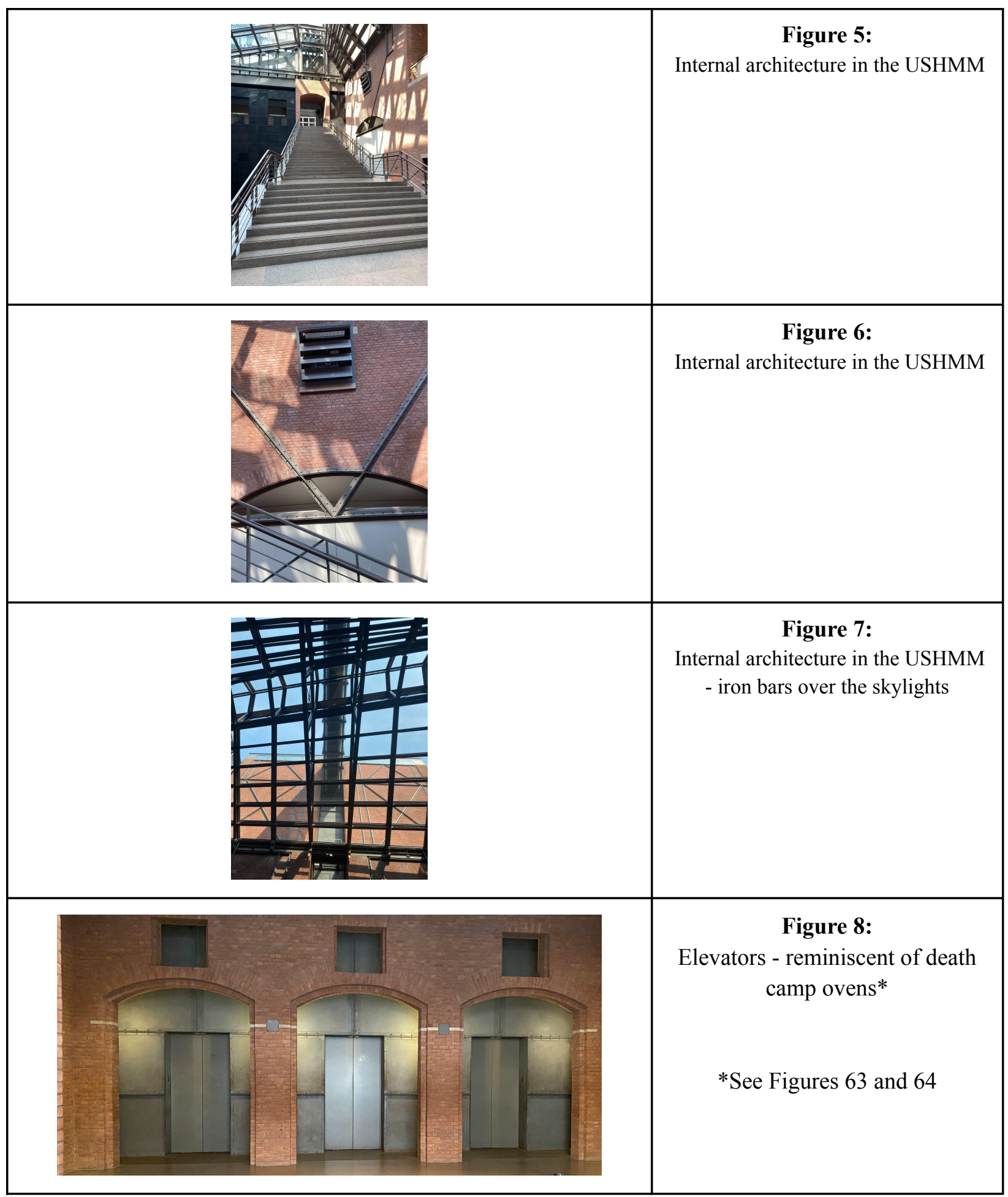




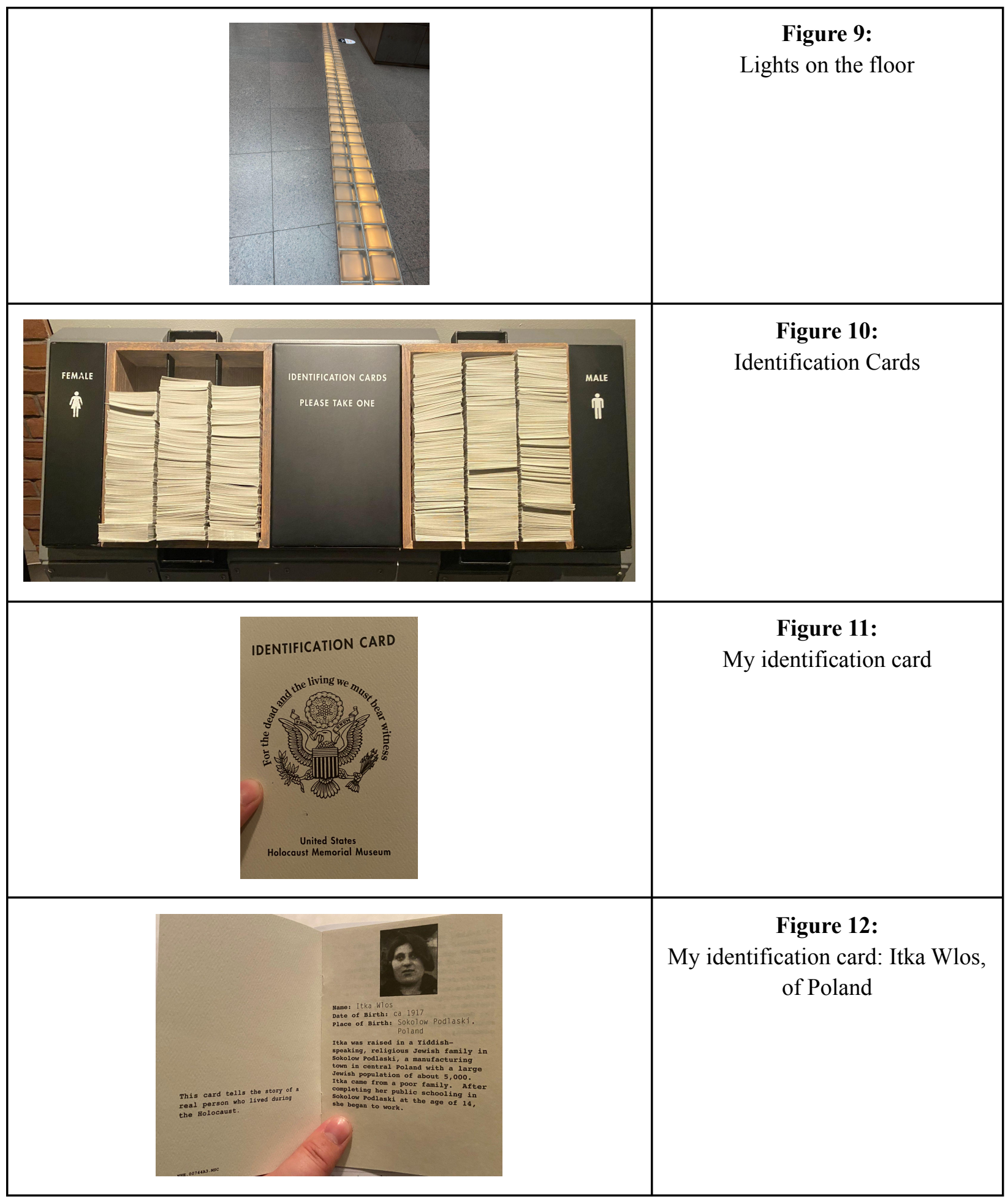




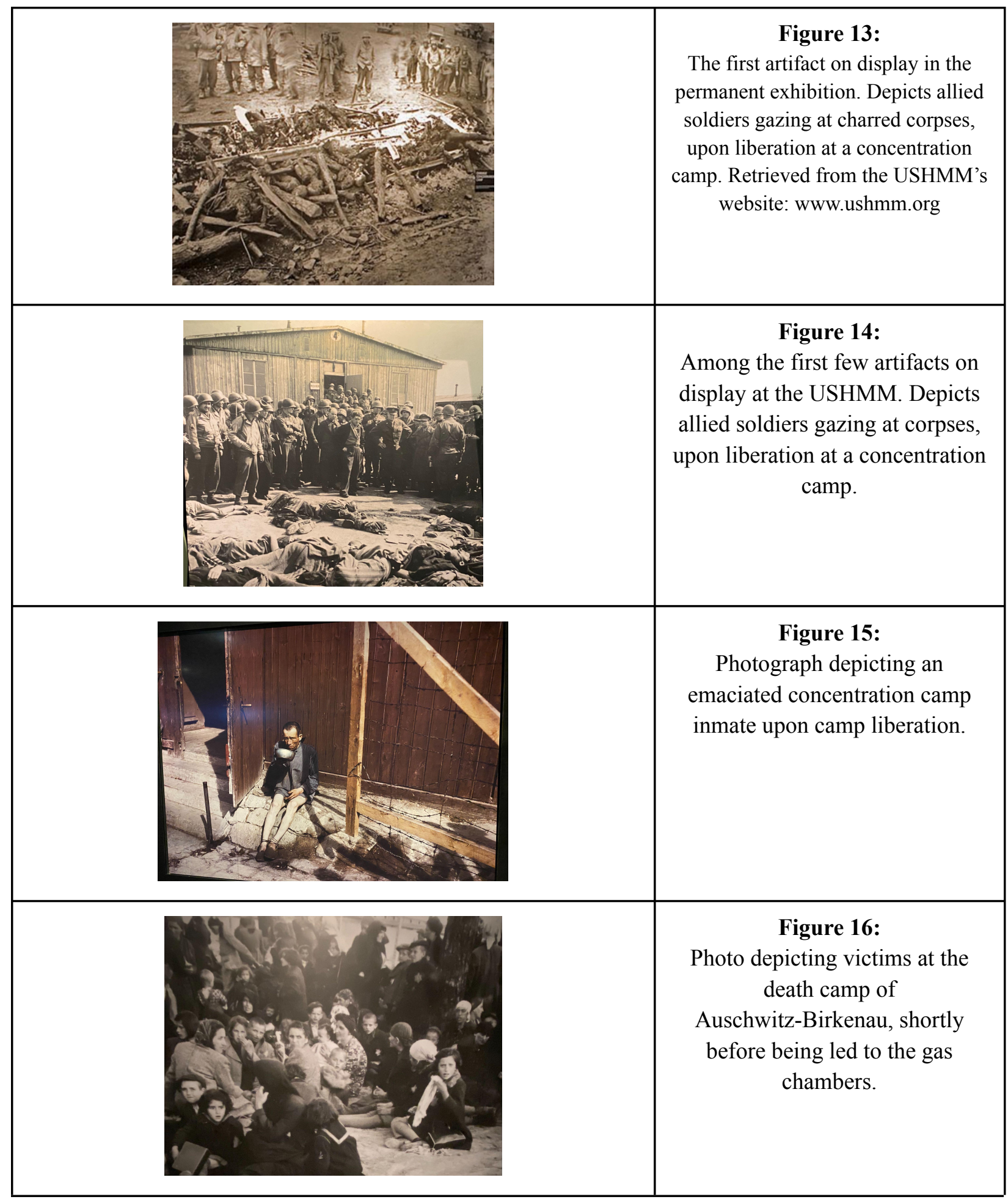




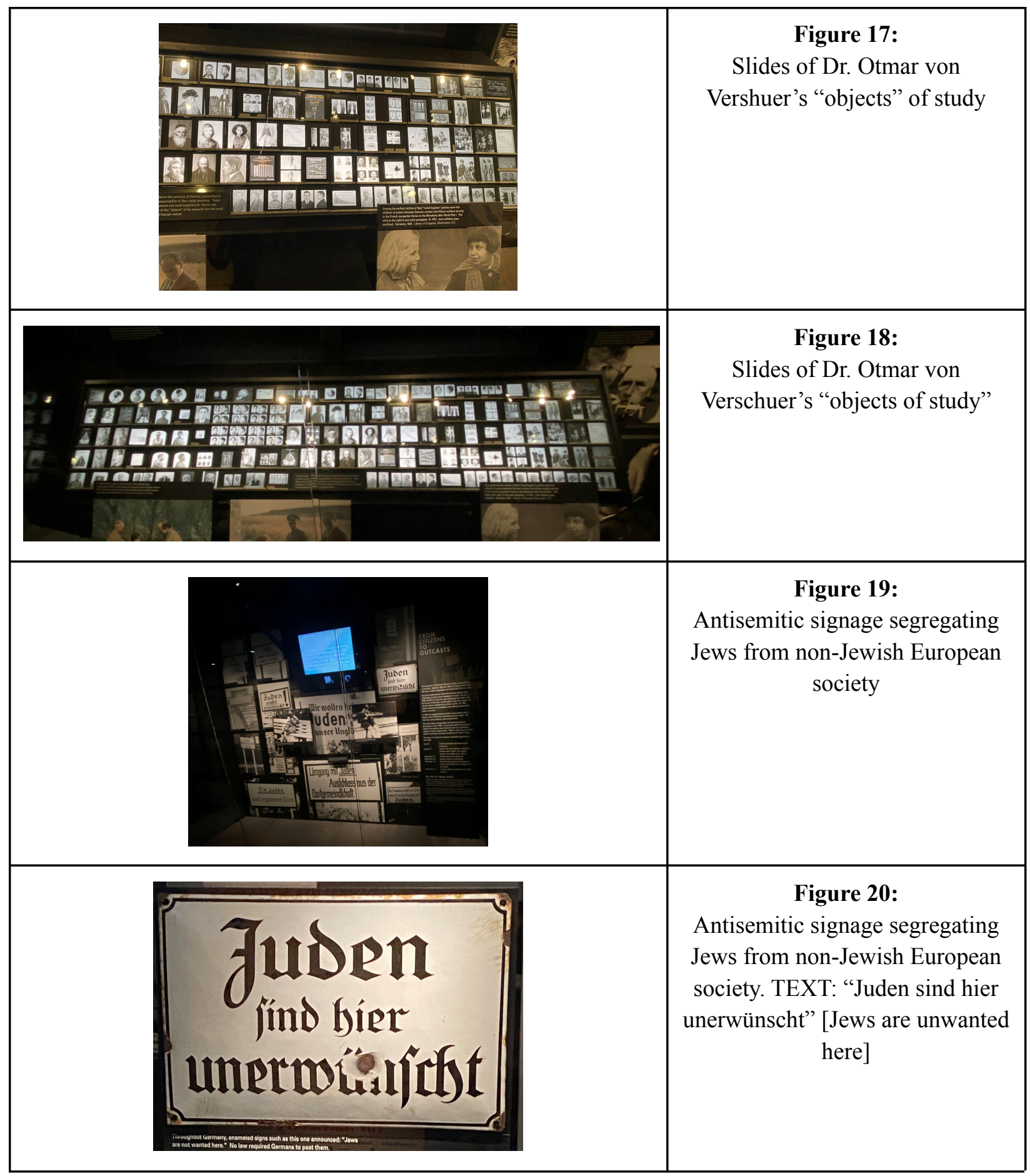




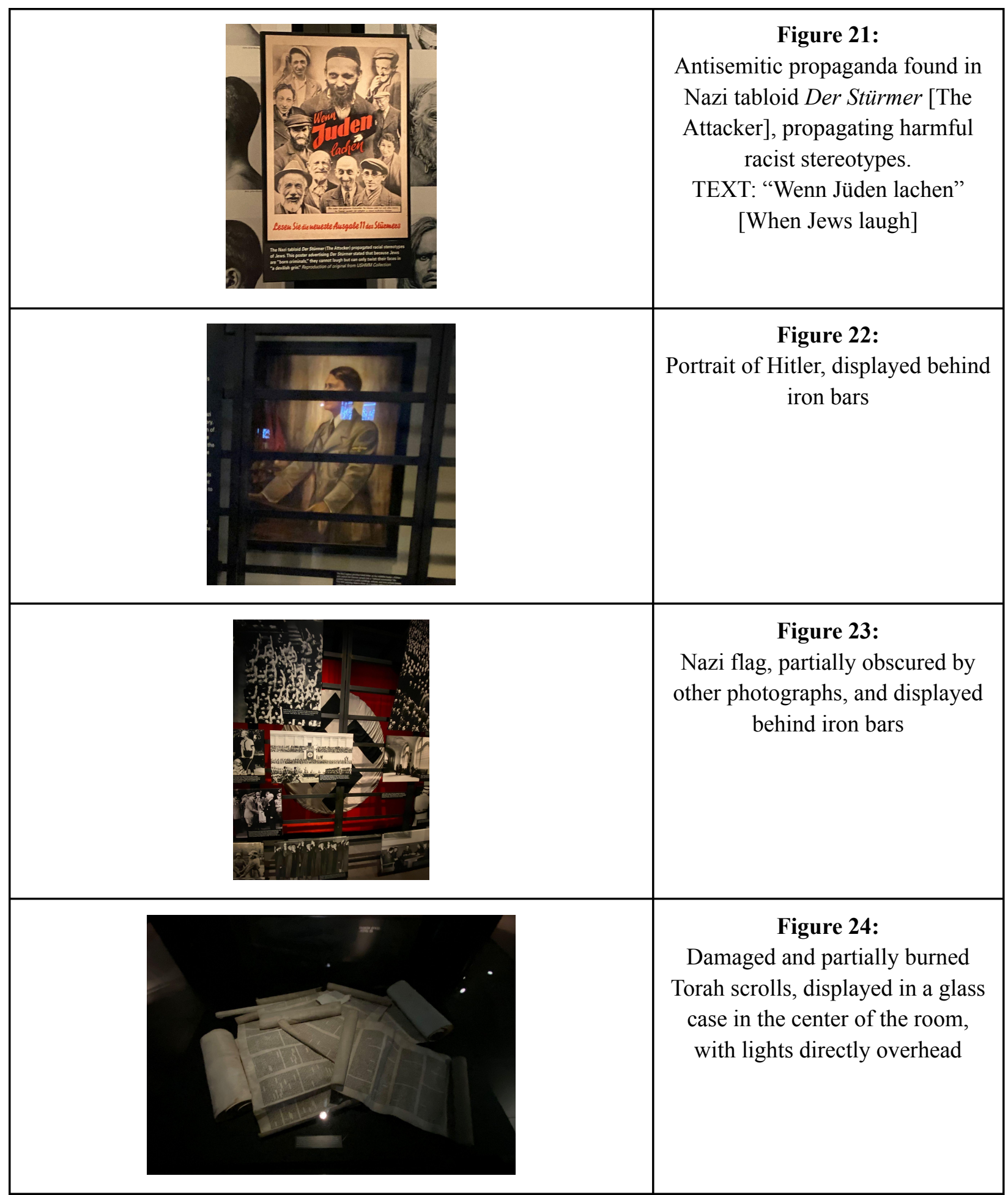




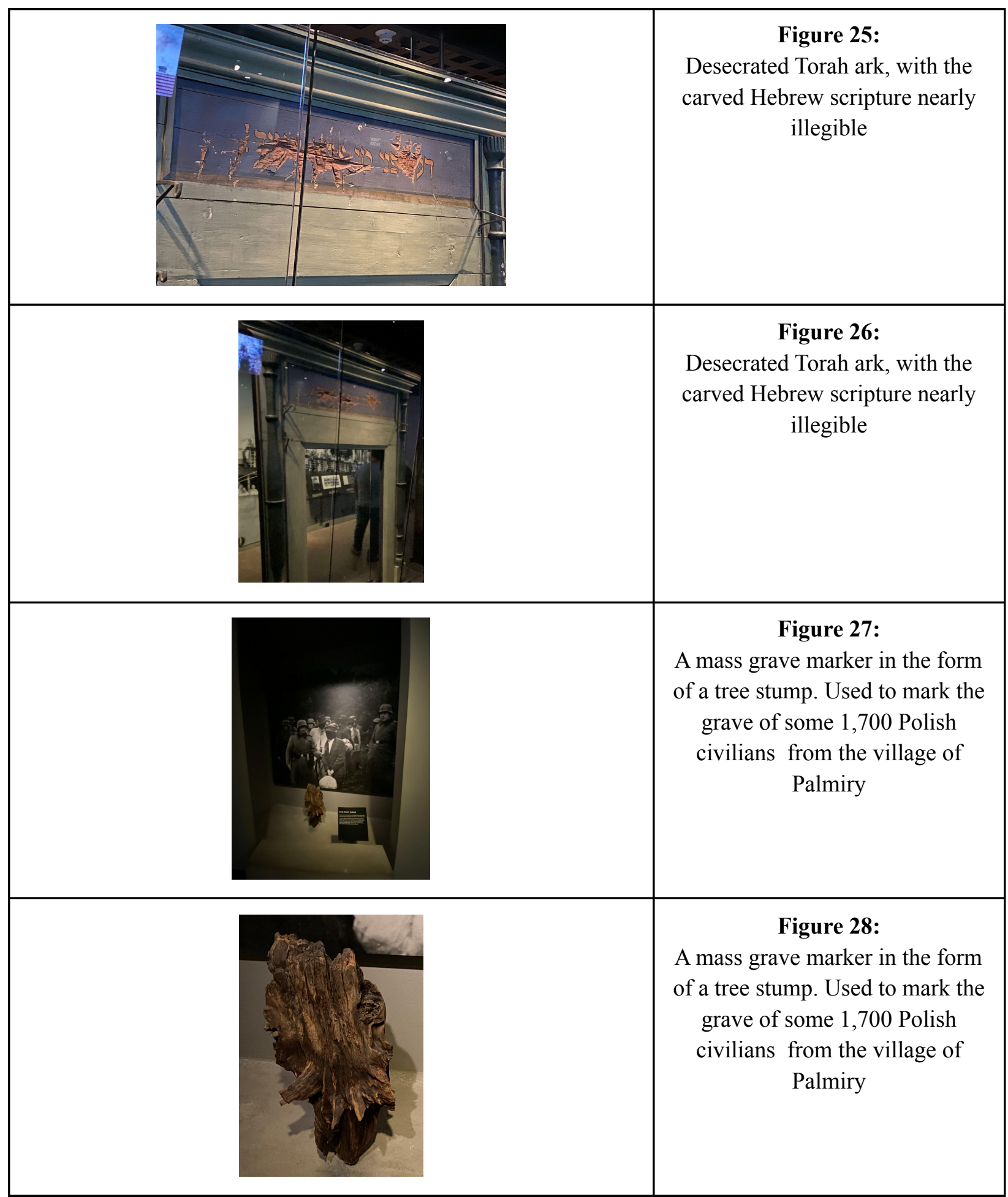




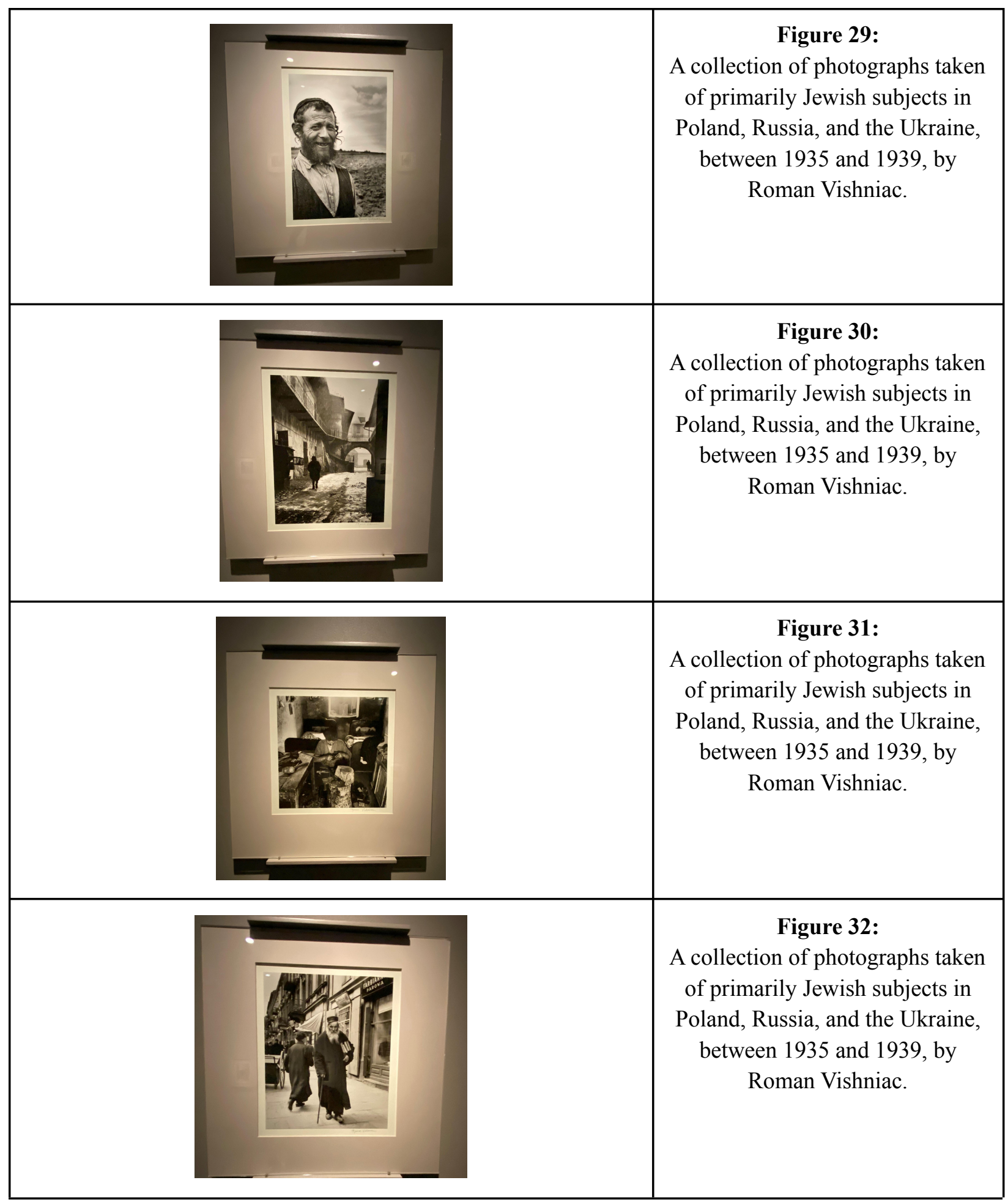




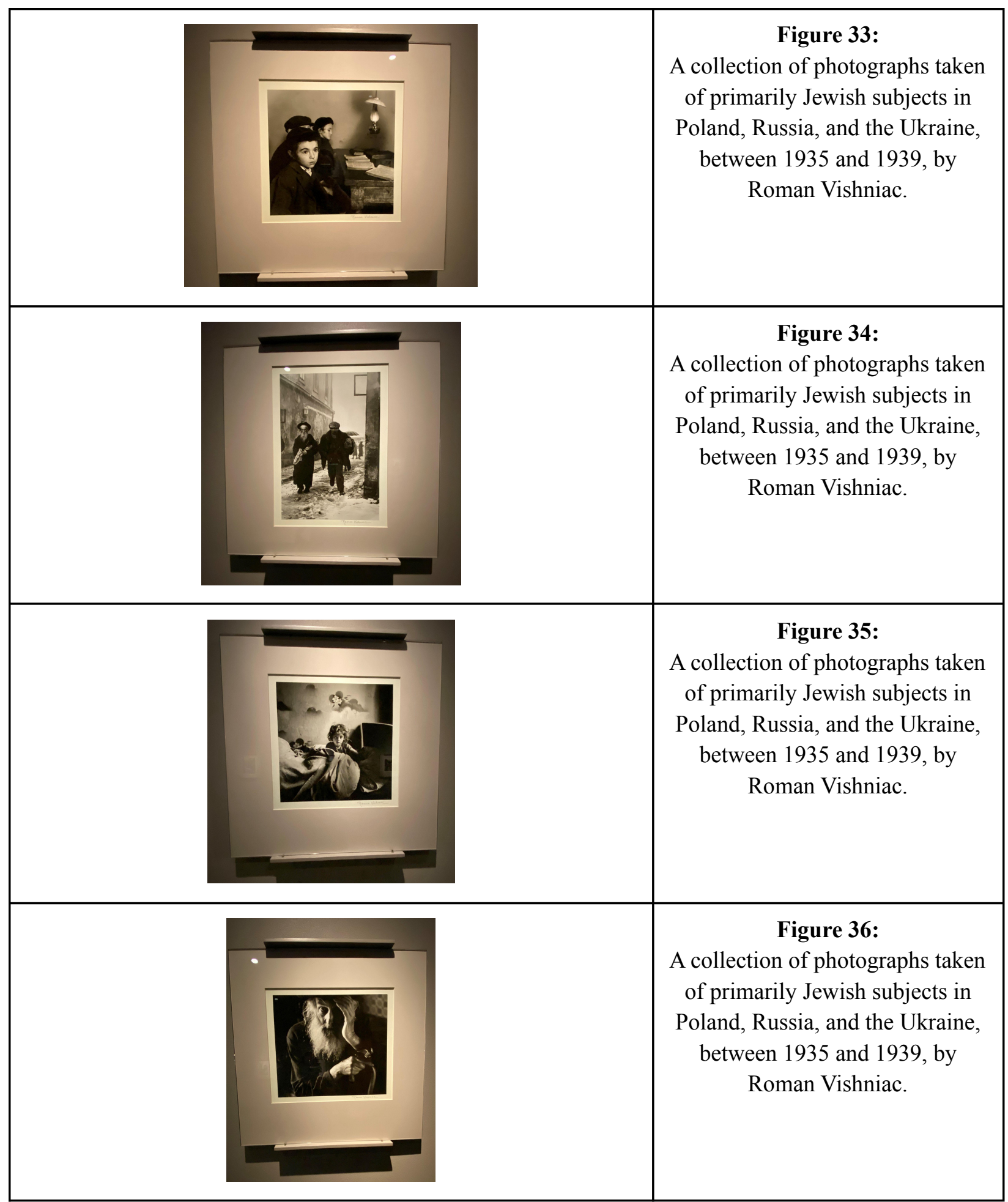




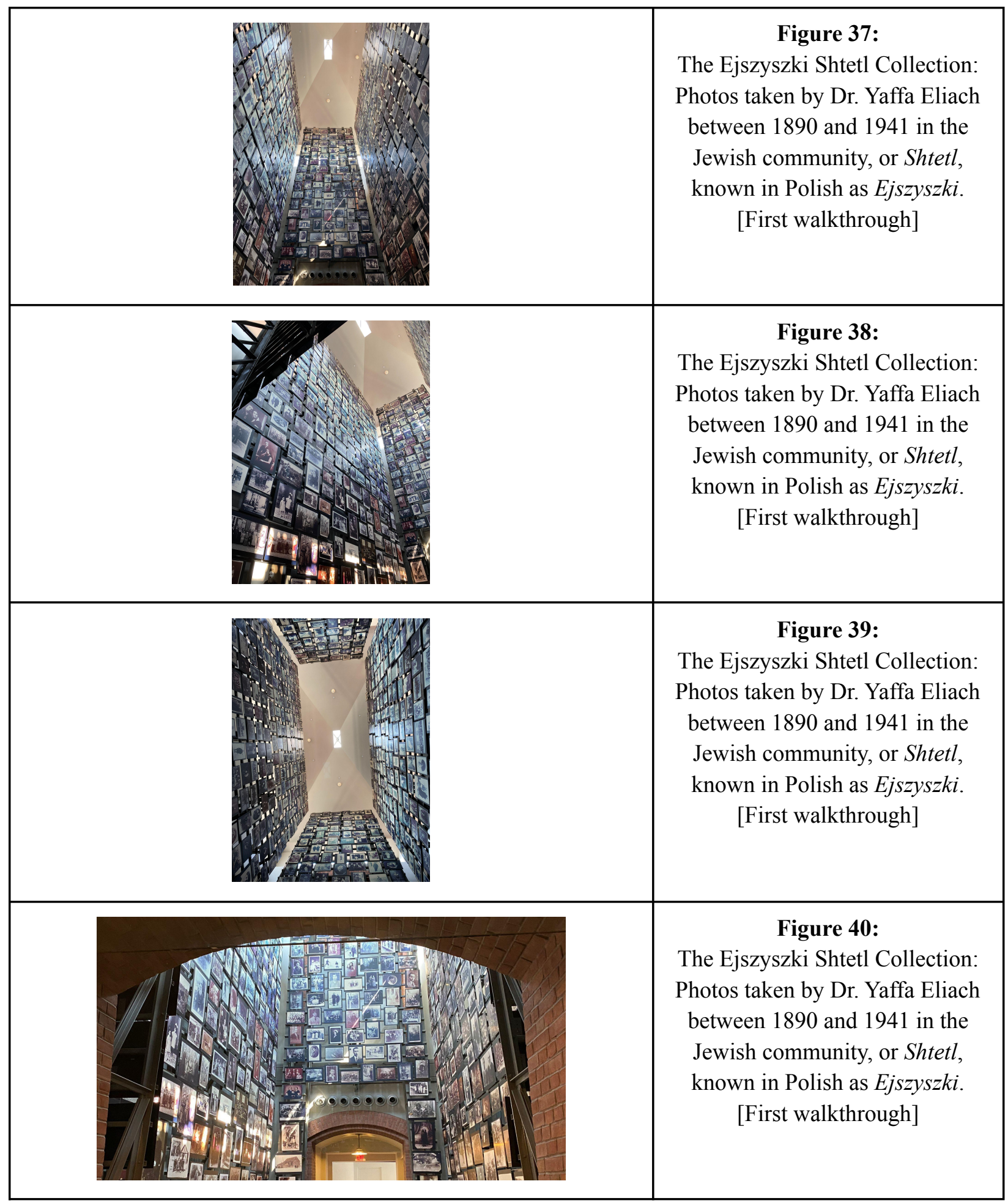




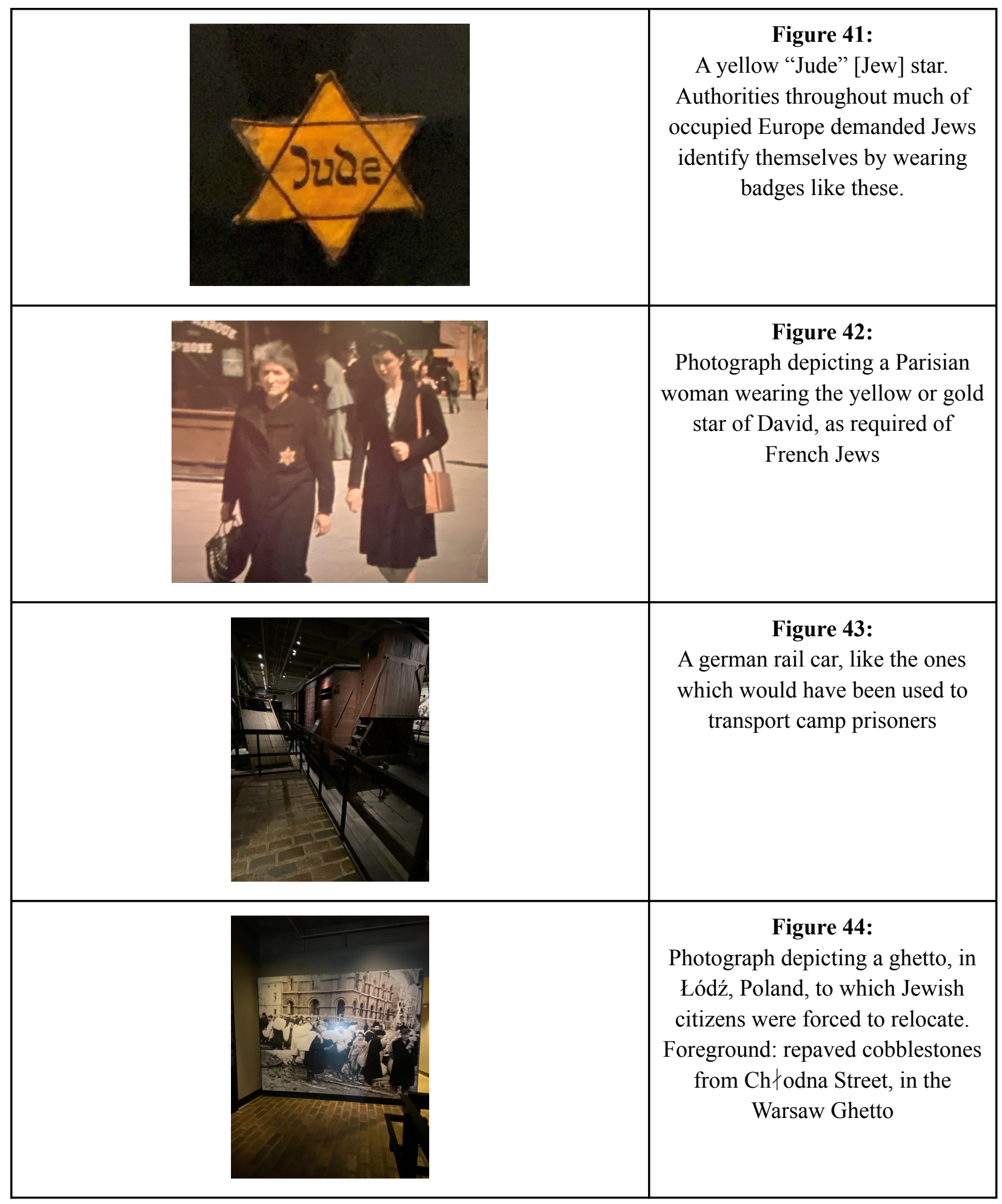




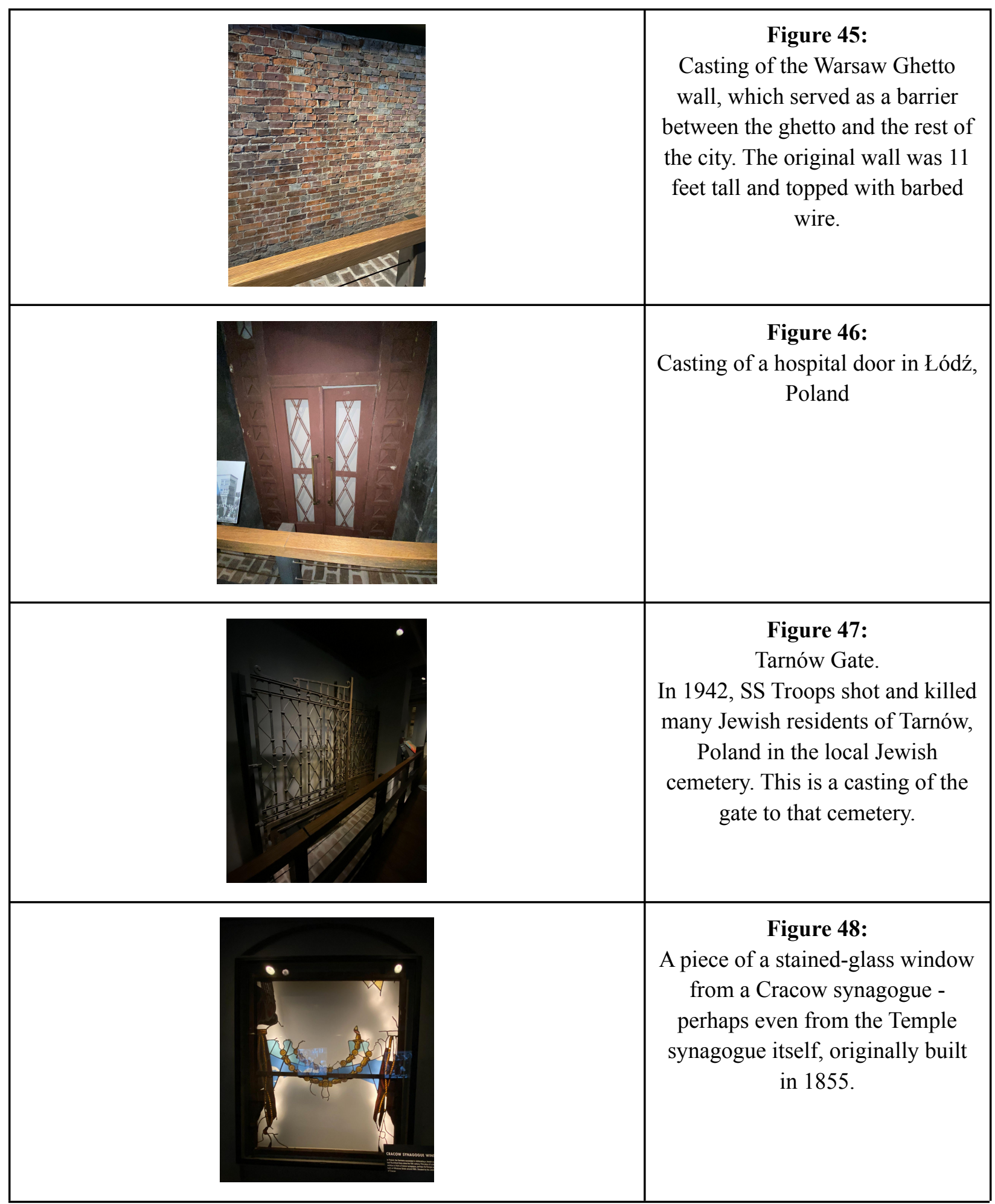




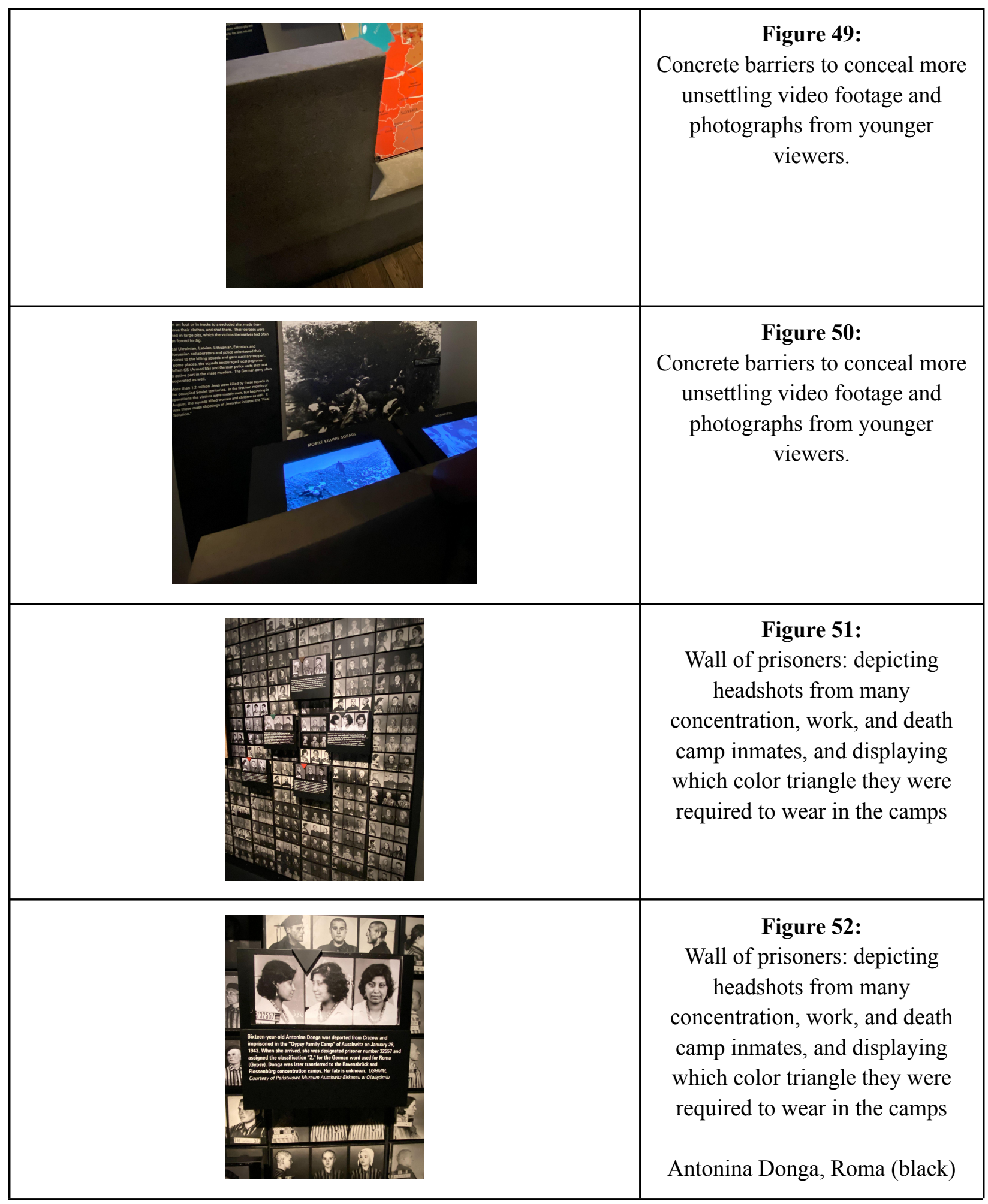




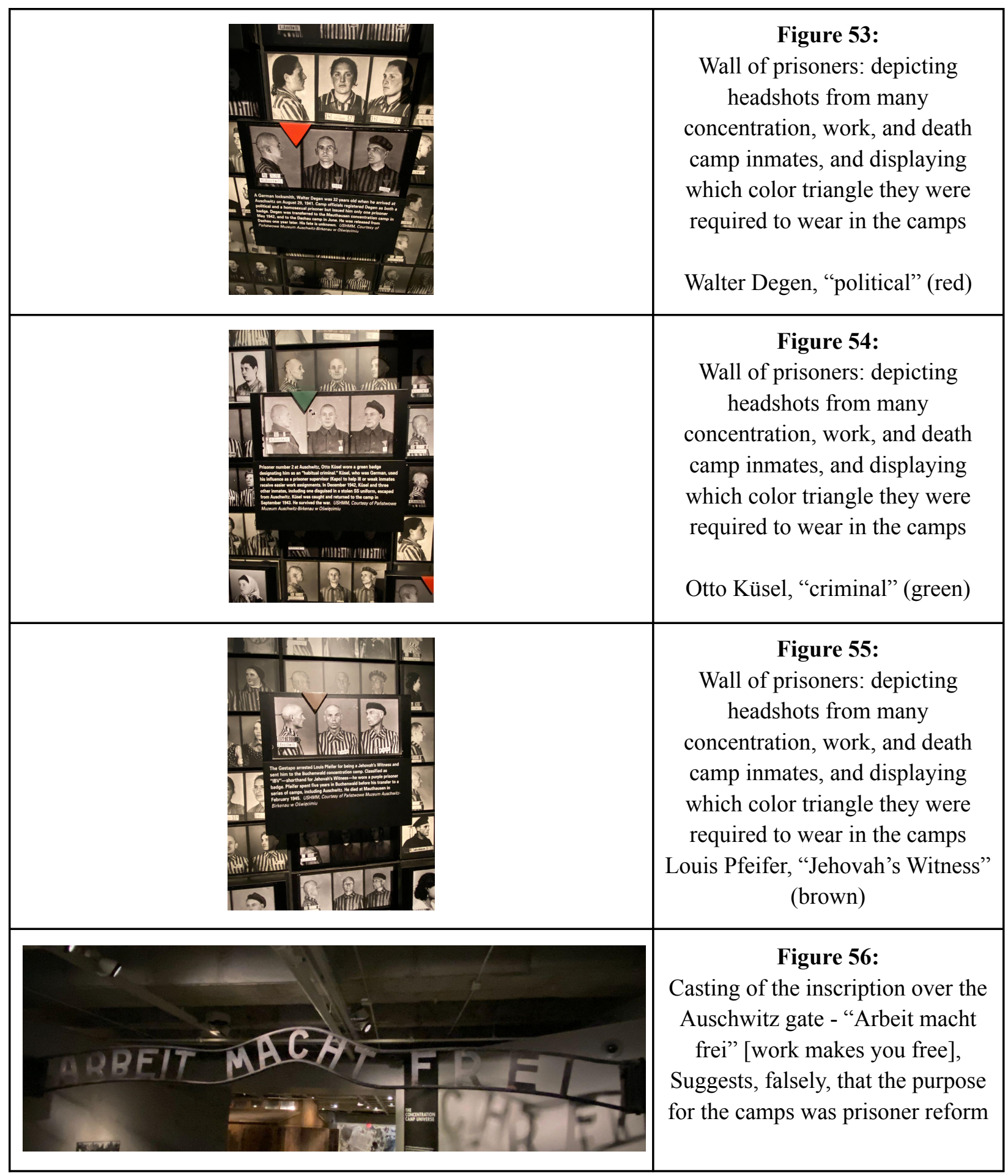




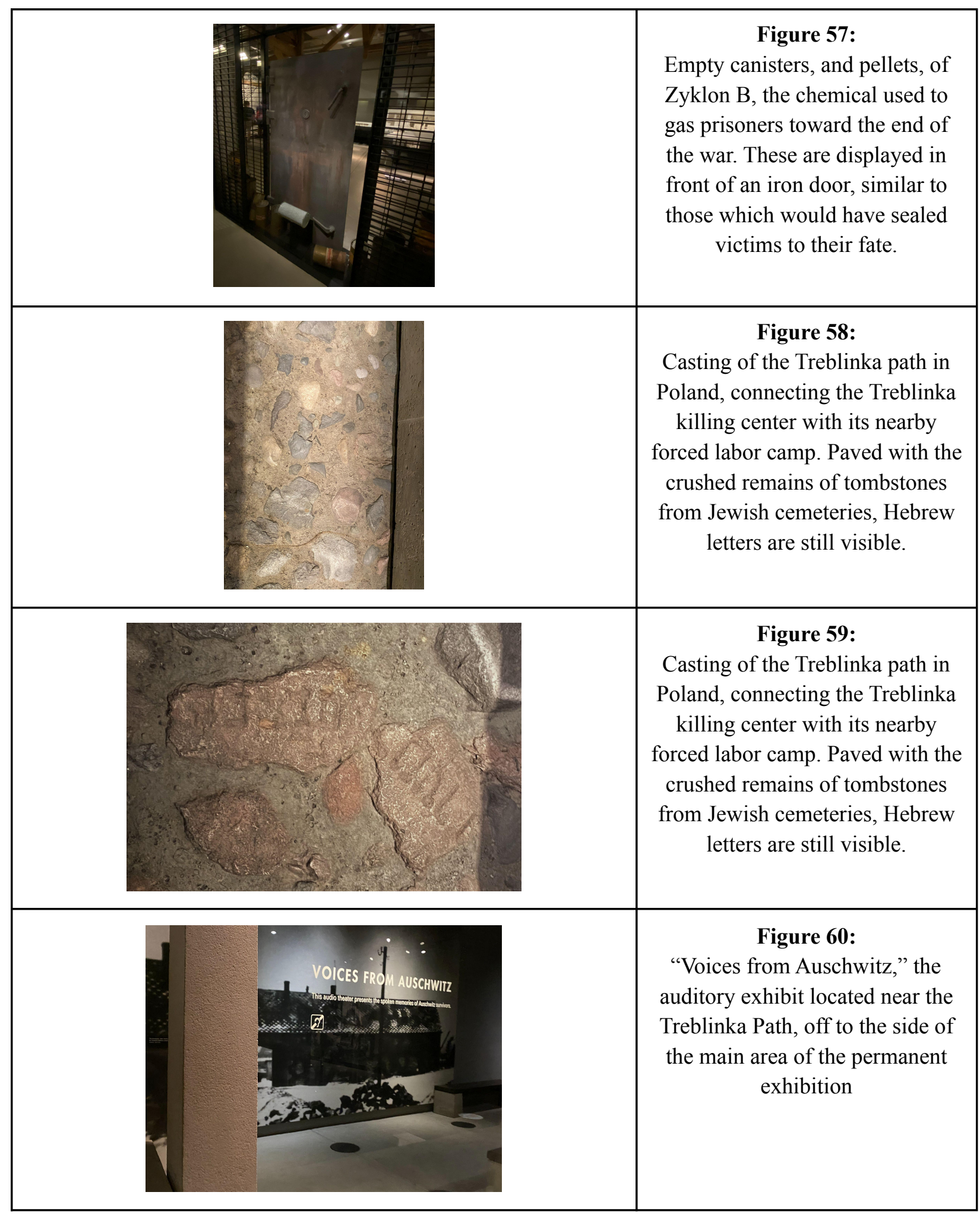




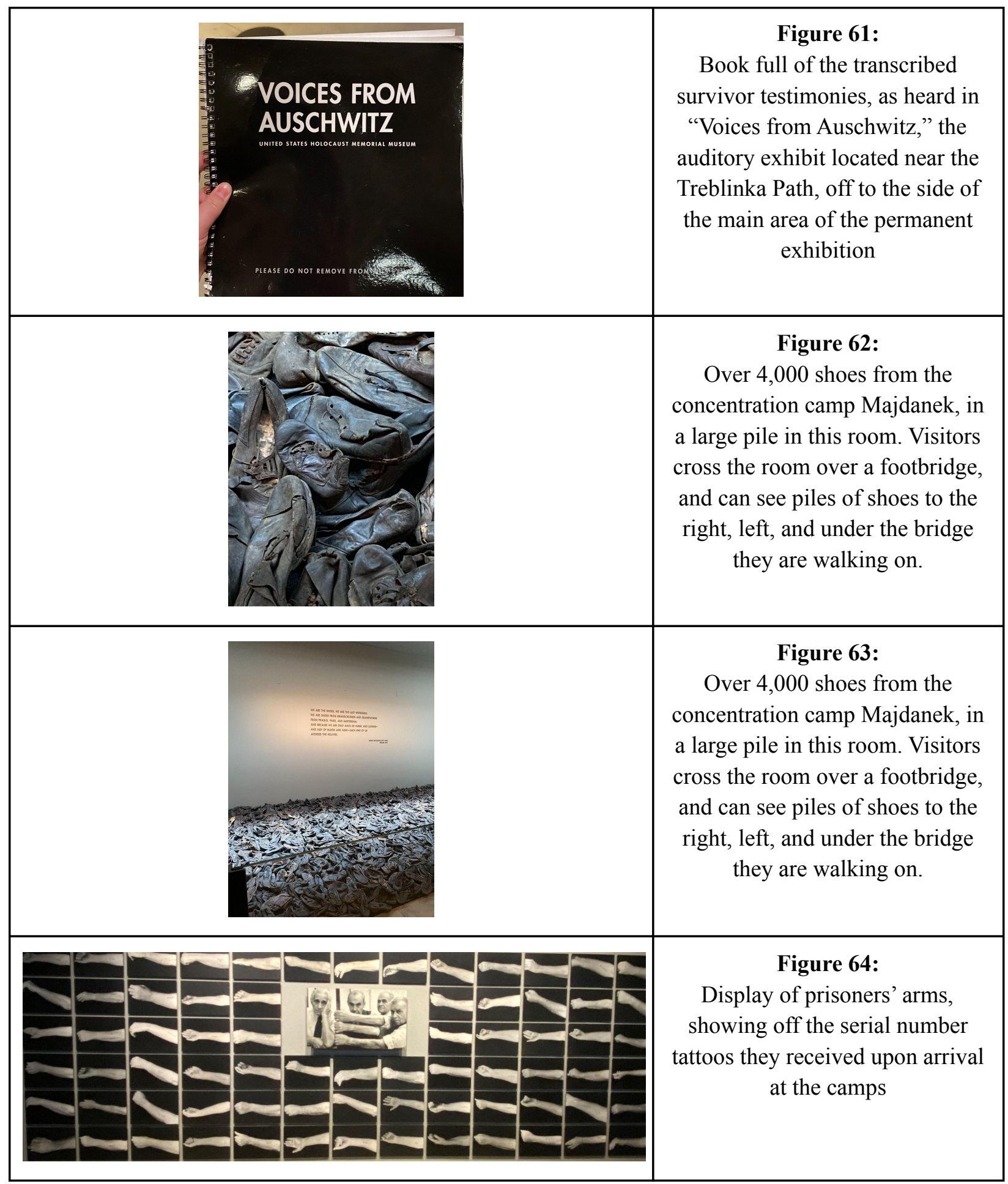




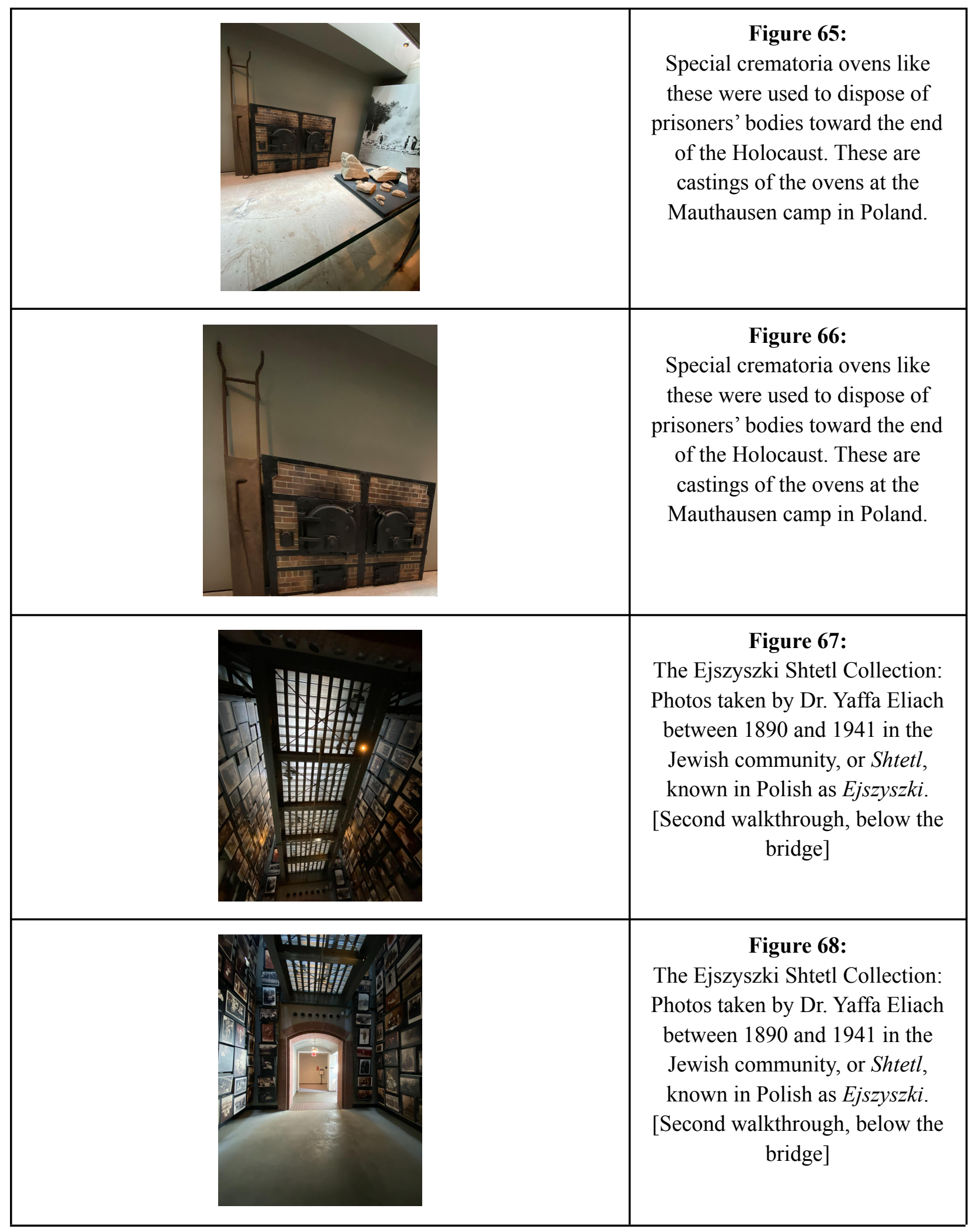




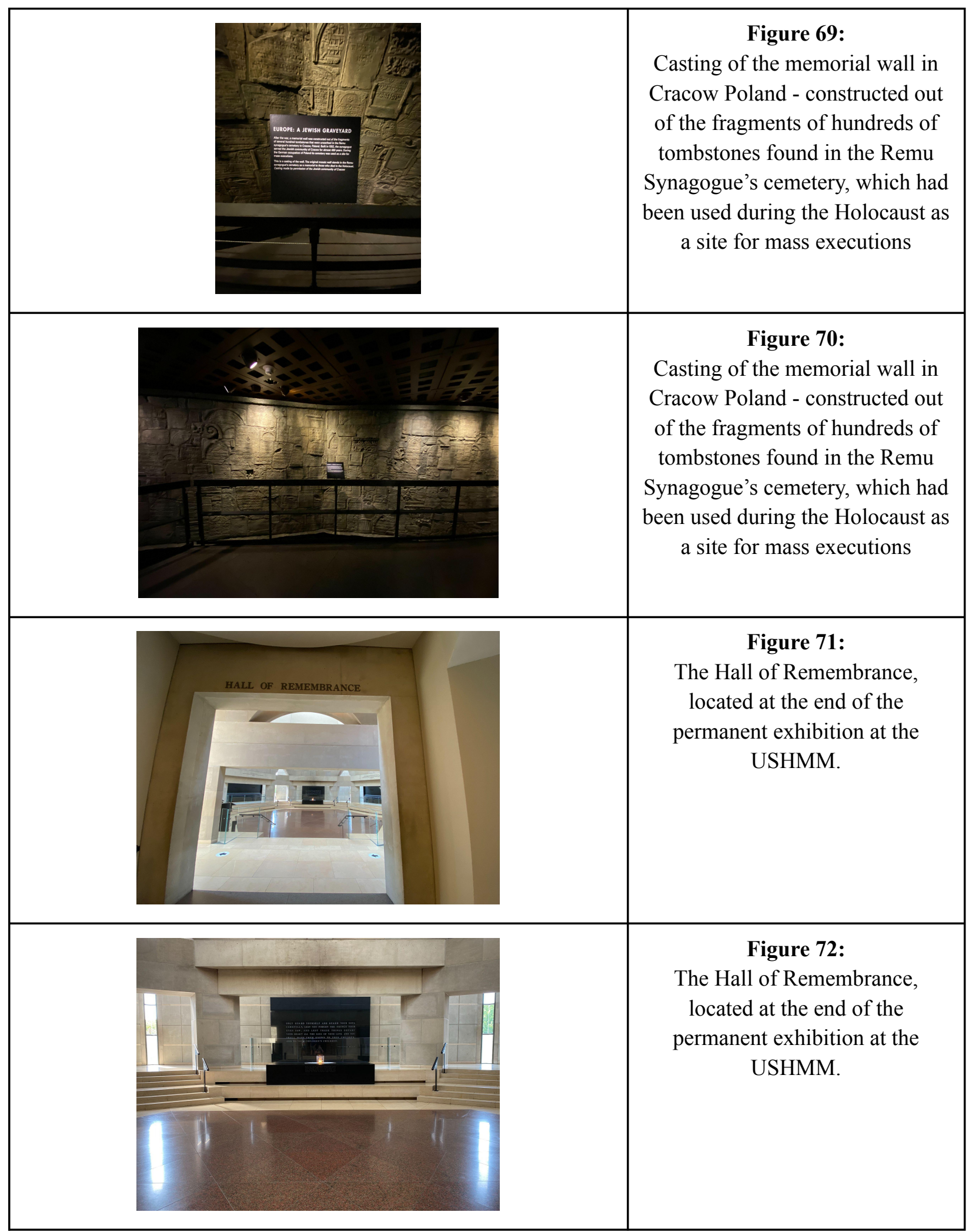




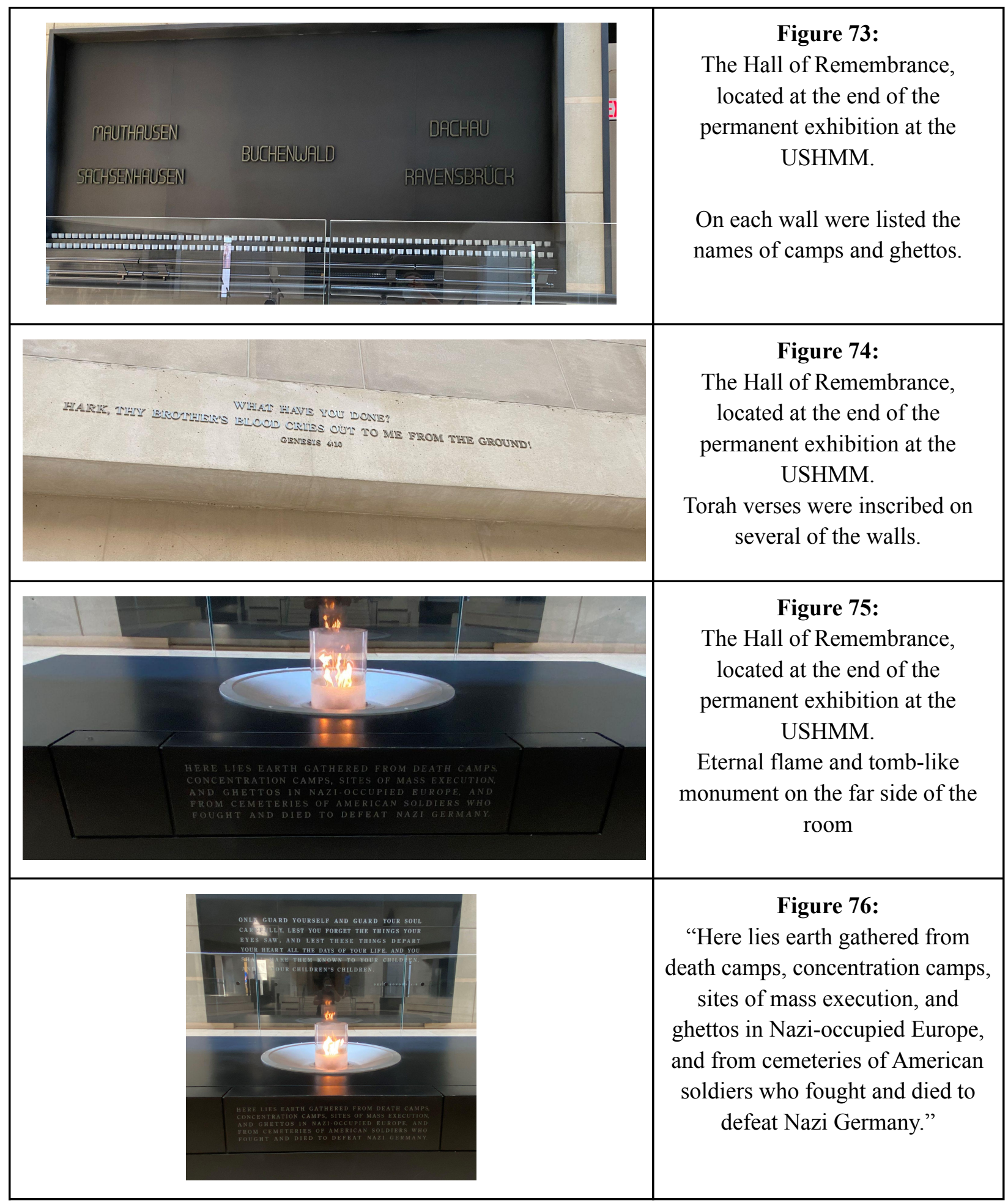




\section{Bibliography:}

"About the Museum: a Living Memorial to the Holocaust." United States Holocaust Memorial Museum. United States Holocaust Memorial Museum. Accessed November 29, 2021. https://www.ushmm.org/information/about-the-museum.

Aharony, Michal, and Gavriel D. Rosenfeld. "Holocaust Commemoration: New Trends in Museums and Memorials.” Dapim: Studies on the Holocaust 30, no. 3 (December 28, 2016): 162-65. https://doi.org/10.1080/23256249.2016.1271088.

Bernard-Donals, Michael F. Figures of Memory: The Rhetoric of Displacement at the United States Holocaust Memorial Museum. Albany: SUNY Press, 2016.

Ellison, David A. "The Spoiler's Art: Embarrassed Space as Memorialization." South Atlantic Quarterly 110, no. 1 (2011): 89-100.

Goh, Robbie B. H. "Memorializing Genocide: Embodied Semiotics in Concentration Camp Memorials." Social Semiotics 28, no. 1 (2018): 18-40.

Goldblatt, Cullen. “Introduction.” Introduction. In Beyond Collective Memory: Structural Complicity and Future Freedoms in Senegalese and South African Narratives, 1-30. New York, NY: Routledge, 2021.

Gopnik, Blake. “Many Words, Little Eloquence.” The Washington Post. WP Company, May 23, 2004. https://www.washingtonpost.com/archive/lifestyle/style/2004/05/23/many-words-little-el 
oquence/9a7ddc40-3304-46ef-ae0f-447600cde4a0/.

Hansen-Glucklich, Jennifer. Holocaust Memory Reframed : Museums and the Challenges of Representation. New Brunswick, New Jersey: Rutgers University Press, 2014.

Hansen-Glucklich, Jennifer. "Poetics of Memory: Aesthetics and Experience of Holocaust Remembrance in Museums." Dapim: Studies on the Holocaust: Holocaust Commemoration: New Trends in Museums and Memorials 30, no. 3 (2016): 315-34.

Halbwachs, Maurice. On Collective Memory. Translated by Lewis A. Coser. Chicago, IL: University of Chicago Press, 1992

Hirsch, Marianne. The Generation of Postmemory: Writing and Visual Culture after the Holocaust. New York, NY: Columbia University Press, 2012.

“History \& Culture.” National Parks Service. U.S. Department of the Interior. Accessed November 15, 2021. https://www.nps.gov/wwii/learn/historyculture/index.htm.

Jacobs, Janet. "Memorializing the Sacred: Kristallnacht in German National Memory." Journal for the Scientific Study of Religion 47, no. 3 (2008): 485-98.

Jinks, Rebecca. "Thinking Comparatively about Genocide Memorialization.” Journal of Genocide Research 16, no. 4 (December 15, 2014): 423-40. https://doi.org/10.1080/14623528.2014.975945.

Meng, Michael. "Monuments of Ruination in Postwar Berlin and Warsaw: The Architectural Projects of Bohdan Lachert and Daniel Libeskind." Comparative Studies in Society and History 59, no. 3 (2017): 550-73. 
Moradi, Fazil., Buchenhorst, Ralph, and Six-Hohenbalken, Maria. Memory and Genocide. Memory Studies. New York: Routledge, 2017.

"National Museum of the American Indian." Smithsonian Institution Archives. Smithsonian Institution Archives, April 14, 2011. https://siarchives.si.edu/history/national-museum-american-indian.

Skidmore, James M. "Memorial to a Haunting Past." Queen's Quarterly 108, no. 4 (2001): 511-519.

Tsiftsi, Xanthi. "Libeskind and the Holocaust Metanarrative; from Discourse to Architecture." Open Cultural Studies 1, no. 1, 2017. 291-303.

"Visiting the Smithsonian National Museum of African American History and Culture: Washington DC.” National Museum of African American History \& Culture | NMAAHC. Accessed November 29, 2021. https://washington.org/visit-dc/guide-to-smithsonian-national-museum-african-americanhistory-culture\#.

Wieviorka, Annette. The Era of the Witness. Translated by Jared Stark. Ithaca, N.Y: Cornell University Press, 2006.

Williams, Paul Harvey. Memorial Museums: The Global Rush to Commemorate Atrocities. English ed. Oxford; New York: Berg, 2007. 